\title{
AS IMPLICAÇÕES DA CRIAÇÃO DE ZONAS DE PROCESSAMENTO DE EXPORTAÇÃO PARA O DESENVOLVIMENTO DO RIO GRANDE DO NORTE
}

\author{
João Paulo Leite Silva \\ Graduado em Comércio Exterior pelo IFRN; graduando de MBA em Comércio Internacional \\ pela FACINTER, atuou na implantação da Central Fácil de Comércio Exterior (CFCE) do \\ SEBRAE/RN; Agente de Comércio Exterior credenciado pela REDEAGENTES do MDIC; \\ assessor-técnico de comércio internacional da CFCE; membro do Comitê Gestor \\ desenvolvendo ações de execução do Projeto Primeira Exportação criado pelo MDIC. \\ E-mail: joaopaulorls@yahoo.com.br \\ Raimundo Nonato Camelo Parente \\ Graduado em Administração de Empresas pela Universidade Estadual do Ceará (1987), \\ especialização em Comércio Exterior pela Universidade Católica de Brasília (2004), mestre \\ em Sistemas e Computação pela UFRN (2002). Atualmente é professor do IFRN. Tem \\ experiência na área de Ciência da Computação. \\ E-mail: rnonato@cefetrn.br
}

\section{RESUMO}

O presente trabalho tem como objetivo compreender as implicações sócio-econômicas e tecnológicas no RN a partir da criação das Zonas de Processamento e Exportação.

Busca, ainda, verificar a repercussão e a influência que as ZPEs têm sobre o mercado exportador do País, bem como, as suas benesses para as regiões nas quais estão implantadas ou com potencial a ser instalado. Identificando os modelos existentes, este estudo pretende apontar aquele que melhor se enquadra à realidade norte-riograndese, assim como seus impactos, no importante cenário da Política Exportadora Brasileira.

Para tanto, utiliza-se de uma abordagem fundamentada em pesquisa bibliográfica, que permitem um diagnóstico descritivo de dados qualitativos e quantitativos, importantes para essa ação. A metodologia escolhida foi à exploratória-descritiva, utilizando-se dados secundários. A pesquisa analisa a estrutura com a qual as estratégias e as políticas de desenvolvimento econômico são colocadas em curso, e, os efeitos gerados, no âmbito macroeconômico, sobretudo, as ZPEs. Ao aliar a teoria à pratica, este trabalho visa proporcionar à sociedade acadêmica, informações acerca das Zonas de Processamento de Exportação e as perspectivas do $\mathrm{RN}$ para o mercado internacional, no aspecto macroeconômico, no qual o país está inserido. Além dos benefícios gerados pelo conhecimento, o aprofundamento do assunto abordado amplia a percepção crítica de alunos e professores, uma vez que possibilita correlacionar situações relevantes do ponto de vista social, político e econômico, mostrando suas interfaces.

Palavras-Chave: Zonas de processamento de exportação, Comércio internacional, Desenvolvimento econômico. 


\title{
THE EFFECTS OF THE CREATION OF PROCESSING ZONES EXPORT DEVELOPMENT OF RIO GRANDE DO NORTE
}

\begin{abstract}
The present work has as objective to understand the partner-economic and technological implications in the RN state from the creation of the Zones of Processing and Exportation (ZPEs).

Search still to verify the repercussion and the influence that the ZPEs have on the exporting market of the Country, as well as, its benefits for the regions in which is implanted or with potential to be installed. Besides observing the existing models, this study intends to identify the ones that better fits to the reality of the people of RN state (norte-riograndeses), as well its impacts, in the important scene of the Brazilian Exporting Politics.

For this, it is used of a boarding based on research bibliographical that allows a descriptive diagnosis of qualitative and quantitative data, important for this action.

The chosen methodology was descriptive, using itself secondary data base. The research analyzes the structure with that the strategies and the politics of economic development are placed in course, and, generated effect, in the macroeconomic scope, over all, the ZPEs.

When uniting the theory to practices, this work aims to provide to the academic society, information concerning the Zones of Processing of Exportation and the perspectives of the $\mathrm{RN}$ for the international market, in the macroeconomic aspect, in which the country is inserted. Beyond the benefits generated for the knowledge, the deepening of the boarded subject extends the critical perception of pupils and teachers, a time, that it makes possible to correlate excellent situations of the social point of view, economic politician and, showing its interfaces.
\end{abstract}

KEY-WORDS: Zones of Processing of Exportation, International trade, Economic development.

\section{AS IMPLICAÇÕES DA CRIAÇÃO DE ZONAS DE PROCESSAMENTO DE EXPORTAÇÃO PARA O DESENVOLVIMENTO DO RIO GRANDE DO NORTE}

\section{INTRODUÇÃO}

O mundo está ficando, relativamente, cada dia menor. A criação dos Blocos Econômicos ${ }^{1}$ e a globalização que, sem dúvida, deverão levar a intensificação das trocas internacionais, exigirão conhecimentos mais amplos sobre o comércio exterior.

É importante destacar que essa é uma das mais antigas práticas comerciais. Começando pelos mercadores, desde os fenícios, passando por Marco Pólo, as primeiras grandes conquistas marítimas e as companhias do comércio exterior o motivo maior foi sempre a riqueza das nações e o fortalecimento das empresas.

Este estudo enfatiza as implicações sócio-culturais e tecnológicas, no Estado do Rio Grande do Norte, a partir da criação das Zonas de Processamento e Exportação. Além disso, procurase verificar a repercussão e a influência que as ZPEs têm sobre o mercado exportador do País, assim como, as suas vantagens para as regiões em que serão implantadas.

\footnotetext{
${ }^{1}$ Blocos Econômicos são estabelecidos por acordos firmados entre Estados com a finalidade de estabelecer relações comerciais e eliminar barreiras.
} 
Sabe-se que, de forma generalizada, a globalização, bem como, os meios de transporte e comunicação atua diretamente para o desenvolvimento das relações comerciais.

A idéia que se têm sobre esse termo não o classifica como um fato, mas, sim, a um processo em constante evolução. Segundo Caldas e Amaral apud Dolam (1998), "a globalização é um processo de gradual eliminação de barreiras econômicas e concomitante aumento nas trocas internacionais e na interação transnacional".

Observa-se, de fato, que atualmente há uma influência cada vez maior desse processo sobre as relações comercias internacionais, inclusive interferindo significativamente na condução de políticas e estratégias, seja de governos ou empresas, em países desenvolvidos ou em desenvolvimento, assim como, nações em transição para a economia de mercado, por exemplo, a China.

O fenômeno da globalização se encontra oculto tanto nas relações de mercado, quanto nas grandes empresas transnacionais, conforme afirma Caldas e Amaral (1998):

“O processo de globalização impõe modificações em todas a áreas do processo produtivo, e argumenta-se, mesmo na vida social, nas relações entre indivíduos e na cultura, de um modo geral, por meio da produção intelectual".

Verifica-se que as organizações se submetem a se reposicionarem e adotarem condutas e estratégias sob uma perspectiva global, apoiadas no fácil acesso aos mercados financeiros e de capital, nas tecnologias de ponta, desconsiderando até mesmo onde estejam situados seus postos de comando.

Vale-se ressaltar também que esse reposicionamento acontece em uma nova perspectiva de acesso aos mercados, uma vez que não se encontra mais somente centrado na propriedade, em produtos tangíveis, mas no acesso e no uso de produtos intangíveis (serviços), como afirmam Caldas e Amaral (1998):

“Além de produtos em si, devem ser levadas em conta as motivações complementares como: a prestação de serviços, a assistência técnica, o financiamento, etc."

Nesse sentido, o comércio não fica restrito somente a produtos materiais e se expande pelas áreas da informação, do conhecimento, da tecnologia e da cultura, estando essas temáticas em pauta nas discussões dos Organismos Internacionais que deliberam sobre as questões multilaterais de comércio.

Nesse mesmo sentido de discussão, é imprescindível destacar que o mundo globalizado conduz a uma nova tendência em que grandes empresas, capitais e mercadorias dispõem de liberdade para se movimentarem. Nessa nova disposição, surge a figura das Zonas de Processamento de Exportação (ZPEs) que se caracterizam por serem áreas de livre comércio com o exterior, destinadas à instalação de empresas voltadas para a produção de bens a serem exportados. Para efeito de controle aduaneiro a ZPE é considerada zona primária e tem a finalidade de fortalecer o balanço de pagamentos, reduzir os desequilíbrios regionais e promover a difusão tecnológica e o desenvolvimento econômico e social. Segundo Bergamini (1996), "todo esse cenário traduz-se na semelhança crescente das estruturas da demanda e na tendência de homogeneização da oferta nos diversos países, o que possibilita a uniformização 
de técnicas de produção e administração, ganhos de escala, na medida em que muda o foco competitivo, que antes se dava do ponto de vista do produto e passa então para o das tecnologias utilizadas no processo de produção".

A participação do Brasil no comércio exterior é pouco expressiva, embora o volume das exportações e importações esteja evoluindo em valores absolutos. Segundo o Serviço de Apoio as Micro e Pequenas Empresas do Rio Grande do Norte - SEBRAE-RN (2006), o percentual estabilizou-se, pois de 1990 até o final de 2007 o país evoluiu de 0,8\% para 0,9\% a sua participação no total do comércio mundial.

O Estado do Rio Grande do Norte, apresenta uma pequena participação (menor que 1\% do PIB) na balança comercial brasileira, embora as micro e pequenas empresas tenham aumentado a participação nesse cenário, segundo o SEBRAE-RN. Vale salientar que este órgão considera: microempresas, as industriais com menos de 20 pessoas ocupadas e exportações anuais até US\$300 mil; pequenas empresas, as industriais com menos de 100 pessoas ocupadas e exportações anuais até US\$ 2.500mil, excluídas as microempresas; e micro e pequenas empresas especiais, as industriais com menos de 100 pessoas ocupadas e exportações anuais superiores a US\$ 2.500 mil, conforme mostra a Tabela I - Distribuição das Micro e Pequenas Empresas no RN. Esses dados servem para enriquecer a base de argumentos que justificam a crescente busca pelas instituições para interagir no cenário internacional.

Tabela I - Distribuição das Micro e Pequenas Empresas no RN

\begin{tabular}{|c|c|c|}
\hline TAMANHO DA & $\begin{array}{c}\text { NÚMERO DE } \\
\text { EMPRESA }\end{array}$ & $\begin{array}{l}\text { EXPORTAÇÕES } \\
\text { ANUAIS (US\$) }\end{array}$ \\
\hline Microempresas (ME's) & 20 pessoas & Até $300.000,00$ \\
\hline Pequenas Empresas (PE's) & Até 99 pessoas & $\begin{array}{c}\text { Entre } 300.00,01 \\
\text { e } 2.500 .000,00\end{array}$ \\
\hline $\begin{array}{c}\text { Micro e Pequenas Empresas } \\
\text { Especiais (MPEE's) }\end{array}$ & Até 99 pessoas & Acima de $2.500 .000,00$ \\
\hline
\end{tabular}

Fonte: SEBRAE-RN

Diante do exposto, verifica-se que essas variáveis contribuem para manter estas empresas no mercado criando mecanismos que possibilitem a sustentação e a evolução da participação do segmento envolvido e é possível observar, também, que outras alternativas tornam viável essa análise de crescimento no mercado norte-riograndense: criação de Zona de Processamento de Exportação. Com isso, a avaliação da dessas variáveis e, sobretudo, das alternativas de fomento ao comércio internacional, tais como ZEPs torna-se o principal objetivo da realização deste Trabalho que é sustentado ainda pelos objetivos específicos de avaliação de pontos positivos e negativos, viabilidade econômica e modelos de implantação com base científica e tecnológica.

O presente objeto de estudo revela a necessidade cada vez mais crescente de colocar questões pertinentes da realidade na qual o Brasil, a Região Nordeste e o Estado do Rio Grande do Norte fazem parte no amplo universo do comércio internacional. Diante das grandes transformações tecnológicas nos meios de comunicação e transporte, além do processo de Globalização, assuntos de natureza político-econômica surgem constantemente em pautas de debate nos mais diversos segmentos. Por essa razão este projeto busca a aproximação com a dinâmica da sociedade dando oportunidade para que se possa reconhecer as relações 
existentes a partir da implantação e desenvolvimento das Zonas de Processamento de Exportação. No âmbito pessoal, esta pesquisa possibilitará o amadurecimento de idéias, argumentos pertinentes à observação dos assuntos relacionados, reconhecimento pela iniciativa pioneira de desenvolver um projeto dessa natureza e maior envolvimento no meio acadêmico. Ao aliar a teoria à pratica, visa proporcionar à sociedade acadêmica, informações acerca do Comércio Internacional, no qual o país está inserido. Além dos benefícios gerados pelo conhecimento, o aprofundamento do assunto abordado amplia a percepção crítica de alunos e professores, uma vez, que possibilita correlacionar situações relevantes do ponto de vista social, político e econômico, mostrando suas interfaces.

Esse projeto justifica-se pelo fato de se constituir uma maneira de dotar o aluno de elementos que são capazes de abrir novos horizontes no meio acadêmico e expressar um esforço real de envolvê-lo em novas significações do tema abordado.

Sendo assim, a relação entre globalização e comércio internacional mostra-se proeminente e faz necessária a figura das ZPEs uma vez que estas apresentam conseqüências diretas sobre a competitividade das empresas e sobre a posição macroeconômica dos países.

Em síntese, são diversas as justificativas para buscar-se inserção no comércio internacional sob a ótica das ZPEs: aumento de oportunidades de negócios; posicionamento competitivo; desenvolvimento nacional, local e regional; e o desenvolvimento profissional com nichos de mercados diversos.

Dessa forma, pretende-se conhecer as implicações da criação de Zonas de Processamento de Exportação para o desenvolvimento do Rio Grande do Norte e observar quais dessas implicações na criação das ZPEs para a alavancar o desenvolvimento do RN?

No que diz respeito aos objetivos geral e específicos, aquele compreende as implicações sócio-econômicas e tecnológicas, no Rio Grande do Norte, a partir da criação da Zona de Processamento de Exportação. Os específicos são: verificar o crescimento da economia norteriograndense com base científica e tecnológica voltados para o Comércio Exterior; identificar os pontos positivos e negativos na criação das ZPEs e o modelo adotado pelo Brasil; analisar um modelo de ZPEs no cenário da economia do Rio Grande do Norte; e identificar os pontos fortes e fracos para implantação de uma ZPE no Rio Grande do Norte.

Visando alcançar os objetivos e a resolução da problemática, o estudo está dividido em referencial teórico, metodologia, resultados e considerações e recomendações.

Sabe-se que, de forma generalizada, a globalização, bem como, os meios de transporte e comunicação atua diretamente para o desenvolvimento das relações comerciais.

A idéia que se têm sobre esse termo não o classifica como um fato, mas, sim, a um processo em constante evolução. Segundo Caldas e Amaral apud Dolam (1998), a globalização é um processo de gradual eliminação de barreiras econômicas e concomitante aumento nas trocas internacionais e na interação transnacional.

Observa-se, de fato, que atualmente há uma influência cada vez maior desse processo sobre as relações comercias internacionais, inclusive interferindo significativamente na condução de políticas e estratégias, seja de governos ou empresas, em países desenvolvidos ou em desenvolvimento, assim como, nações em transição para a economia de mercado, por 
exemplo, a China. O fenômeno da globalização se encontra oculto tanto nas relações de mercado, quanto nas grandes empresas transnacionais, conforme afirma Caldas e Amaral (1998): Amaral (1998): “O processo de globalização impõe modificações em todas a áreas do processo produtivo, e argumenta-se, mesmo na vida social, nas relações entre indivíduos e na cultura, de um modo geral, por meio da produção intelectual".

\section{GLOBALIZAÇÃO}

Mais que um processo de sentido ideológico e com significado histórico, a globalização é caracterizada pela interatividade e inter-relação entre costumes e posturas distintas de indivíduos e organizações ocorridos simultaneamente nos quatro cantos do mundo. Esse processo de mudanças, apesar de batizado recentemente na década de 80 , vem se desenvolvendo há séculos acompanhando a evolução humana desde as sociedades primitivas até a atualidade, conforme menciona RUIZ (2003):

\footnotetext{
"A humanidade desde o início de sua existência vem evoluindo, passou de uma simples família para tribos, depois foram formadas as cidades-estado, nações e hoje com a interdependência de todos os povos do nosso planeta, chegamos a um fenômeno natural, denominado de "aldeia global"".
}

Sentido amplo que contempla implicações com repercussões mundiais, o processo de globalização é dividido em fases - Primeira Fase, Segunda Fase e Globalização Recente - nas quais é possível verificar o que houve e quais os efeitos.

Antes de mencionar a Primeira Fase, é importante se fazer uma contextualização da época, porque, sabe-se que anteriormente às Navegações as sociedades já viviam de forma organizada e que, embora fossem distintas entre si, elas tinham algo em comum: uma organização que se desenvolvia estimulando o crescimento econômico de acordo com a região em que viviam (Aztecas - México, Incas - Peru, Mesopotâmicos - às margens do Tigre, Eufrates e Nilo). RUIZ (2003) suscita exatamente isso em:

"Durante milhares de anos elas desconheceram-se e nem imaginavam que algum dia poderiam estabelecer relações significativas."

\section{PRIMEIRA FASE DA GLOBALIZAÇÃO}

Fazer a relação correta entre economia e cultura ou ao que chamamos de "integração econômica e cultural", segundo RUIZ (2003), ou simplesmente globalização é uma árdua tarefa na qual poucos se arriscam devido às controvérsias em se estabelecer uma periodização. Conforme os critérios de MAURO há dois momentos: de 1492 até 1792 - período em que, segundo ele, a "Revolução Francesa e a Revolução Industrial levam a Europa, que liderou o processo inicial da globalização, à voltar-se para resolver suas disputas e rivalidades" - e de 1870 em diante - quando se desenvolvem os novos meios de transporte e navegação como a estrada-de-ferro e o navio a vapor. 
Diante desse posicionamento, Wallerstein apud RUIZ (2003) coloca-se contrário a uma divisão em dois períodos devido ao fato desse processo nunca ter sido interrompido, independentemente de batalhas ou "macro-estratégias militares para acossar os adversários".

Nesse sentido, a primeira globalização é resultado da procura de uma rota marítima para as Índias fruto do expansionismo mercantilista que estabeleceu as primeiras feitorias comerciais européias na Índia, China e Japão, e abriu aos conquistadores europeus as terras do Novo Mundo.

\section{SEGUNDA FASE DA GLOBALIZAÇÃO}

Fruto do processo de industrialização, do imperialismo2 e do colonialismo3, a segunda globalização durou um século e iniciou-se a partir de 1850. Mudanças nos meios produtivos, passando do trabalho artesanal para o manufaturado, aumento da produção e maior rendimento na produtividade e a diminuição das distâncias com a melhoria nos meios de transporte e comunicação fez dessa fase uma das mais ricas em termos de transformações sócio-político-econômicas. Segundo MARX (1848) apud RUIZ (2003):

“(...) Em lugar das antigas necessidades satisfeitas pela produção nacional, encontramos novas necessidades que querem para a sua satisfação os produtos das regiões mais longínquas e dos climas os mais diversos. Em lugar do antigo isolamento local...desenvolvem-se, em todas as direções, um intercâmbio e uma interdependência universais."

Período de efervescência entre culturas, economias e interesses distintos, fez do choque do imperialismo que levou a conflitos bárbaros, como a I e a II Guerras Mundial, e grandes modificações no cenário mundial. Dessa maneira, essa fase da globalização é caracterizada pela materialização de seu significado frente às mudanças advindas de tais transformações.

\section{GLOBALIZAÇÃO RECENTE}

Desestatização da economia, crescente influência do capital especulativo e avanço significativo nas tecnologias de comunicação marcam consideravelmente atualidade desse processo chamado globalização, segundo DEL ROIO (2005):

\footnotetext{
“A forma política da dominação do capital tem passado por mudanças significativas a partir das últimas duas décadas, precisamente nesse período que vem sendo chamado de globalização”.
}

\footnotetext{
2 Imperialismo é a política de expansão e domínio territorial e/ou cultural e econômico de uma nação sobre outra, ocorrido na época da segunda revolução industrial

${ }^{3}$ Colonialismo é a política de exercer o controle ou a autoridade sobre um território ocupado e administrado por um grupo de indivíduos com poder militar, ou por representantes do governo de um país ao qual esse território não pertencia, contra a vontade dos seus habitantes que, muitas vezes, são desapossados de parte dos seus bens e de eventuais direitos políticos que detinham.
} 
Embora essa fase esteja sendo vivenciada com lembranças do passado, tais como as marcas deixadas pelo colonialismo, nas regiões exploradas pelo Mercantilismo4 (Primeira Globalização) e pelos atropelos da Revolução Industrial (Segunda Globalização) que ainda repercutem na modelo produtivo (mais-valia), não há registros da valorização acentuada do conhecimento como vem sendo verificado neste momento.

\section{DESENVOLVIMENTO ECONÔMICO BRASILEIRO}

O Brasil tem seu histórico sócio-econômico relacionado aos ciclos e subcíclos econômicos de produtos que ao longo do tempo, a partir da chegada dos europeus, eram explorados no território nacional. Dessa maneira, a era do Pau-brasil, primeira riqueza natural a ser explorada pela Coroa Portuguesa, foi seguida pela produção voltada para a cana-de-açúcar, ouro, cacau, tabaco e cedendo espaço, em determinado momento - surgimento da República Velha5, ao café. Foi esse produto que permitiu ao país encontrar o seu caminho no processo de industrialização. Embora tenha sido muito oportuna, essa etapa do desenvolvimento brasileiro, ela é vista por alguns autores, como A. Lacerda, et. all. (2000), como "um processo tardio". Esse posicionamento coletivo tem origem nas políticas citadas anteriormente, como o colonialismo, a fase de expansão cafeeira que levou ao processo de interiorização (ocupação do Centro-Sul do país) até o período no qual houve a "substituição das importações" brasileiras, como afirmam os autores A. Lacerda, et. all. (Economia Brasileira, 2000):

A segunda fase da "luta pela industrialização" situa-se no período da Primeira Guerra, quando as potências capitalistas, momentaneamente, sustaram o fornecimento de manufaturas, deixando um espaço vazio que deu origem ao processo de "substituição das importações".

O contexto no qual se trata tal afirmação corresponde ao período da Segunda Guerra Mundial onde o Brasil teve sua participação direta juntamente aos Aliados ${ }^{6}$ fornecendo equipamentos, suprimentos e tropas. A entrada do país no Conflito foi um fator que contribuiu positivamente para o desenvolvimento da indústria nacional.

A partir da Segunda Guerra, o Brasil passou pelo segundo governo Vargas (1951-1954), onde vivenciou grandes projetos energéticos, como a criação da Companhia Siderúrgica Nacional (CSN) e a Empresa de Petróleo Brasileiro (Petrobras) que serviram para estimular o desenvolvimento da indústria de Base. Em relação a essa política nacionalista, os autores já mencionados afirmam que:

"Para compensar a entrada de investimento estrangeiro no setor energético, onde uma considerável soma de capital norte-americano de

\footnotetext{
${ }^{4}$ Mercantilismo é a uma corrente de pensamento econômico desenvolvido na Europa na Idade Moderna, entre o século XV e os finais do século XVIII, que originou um conjunto de medidas econômicas diversas de acordo com os estados. É possível distinguir três modelos principais: bulionismo, colbertismo e mercantilismo comercial e marítimo

5 A Quarta República Brasileira ou República Velha foi o período da história do Brasil que vai da proclamação da República, em 1789, até a Revolução de 1830.

6 Aliados: Grupo de países que se uniram aos Estados Unidos e Reino Unido, antes contra a Alemanha na Primeira e Segunda Guerra Mundial e depois se generalizou passando a designar as forças "ditas" do bem contra os seus opositores quer sejam do bem ou do mal.
} 
cerca de 400 milhões de dólares foi utilizada, Vargas promoveu um maciço movimento de nacionalização do petróleo, sob o lema ' $O$ petróleo é nosso', instituindo mecanismo legais que assegurava ao Estado o monopólio da exploração e do refinamento do petróleo nacional."

Nos anos que se seguiram, o país passou pelo governo Juscelino Kubitschek (JK), onde teve grandes resultados, João Goulart e a era dos militares.

Com a morte de Vargas em 1954, Juscelino assumiu a presidência do país até 1956. O Governo J.K. teve uma política econômica chamada de "Plano de Metas", previa a consolidação da substituição de importações, investimento do Estado no setor público correspondente às Parcerias Público-Privada (PPP) atuais, como a construção de estradas e Brasília, fortalecimento da indústria da Base - criação da Usiminas e Cosipa - e do setor energético - construção das barragens de Furnas e Três Marias.

O Plano procurava contemplar os setores estratégicos da economia: transporte, energia, indústria básica, alimentação, educação e a construção da nova capital, Brasília, que promovia a interiorização da administração do país.

O ambicioso Programa de Metas do governo J.K. permitiu um salto grandioso no desenvolvimento econômico brasileiro. O "nacional-desenvolvimentismo" contribui para o desenvolvimento dos meios de transporte e comunicação - implantação da indústria automobilística e a abertura de estradas que permitiram a integração regional.

O Governo Jango, como era chamado João Goulart, não teve resultados tão expressivos como o seu antecessor. Porém, acompanhando as instabilidades internacionais, verifica-se que no início da década de 60 o Brasil ainda estava em crescimento, mas no final de 62 e em 63 entra em recessão. A instabilidade política no curto governo de Jânio Quadros, motivada pelo fracasso do Plano Trienal que, em virtude de uma recessão, concentração monetária, descontrole da inflação e dependência do setor externo, levou a uma queda na atividade industrial e contribuiu para o Golpe Militar de 1964.

Implantado o Regime Militar, em meio à crise política, encerra-se o ciclo de governos populistas, como Getúlio. Com a ascensão dos militares ao poder grandes transformações internas, como as Reformas Bancária - onde se criou o Banco Central, o Conselho Monetário Nacional e foi instituída a correção monetária para diminuir os efeitos da inflação, e Tributária - na qual se criou o Fundo de Garantia por Tempo de Serviço (FGTS), Programa de Integração Social (PIS) e o Programa de Formação do Patrimônio do Servidor Público (PASEP) com o objetivo de aumentar a arrecadação. O Regime "tecnocrático-modernizante" adotou um modelo desenvolvimentista que tinha como objetivo normalizar as relações com organismos financeiros internacionais. Dessa maneira, o Ministério do Planejamento instituiu o Plano de Ação Econômica do Governo (PAEG) e as bases do milagre econômico vivenciado posteriormente.

O PAEG permitiu o aumento dos investimentos, a estabilidade de preços (prioridade) e a diminuição dos desequilíbrios regionais e déficits do Balanço de Pagamentos. Em contrapartida, ocorreu a inflação devido ao excesso de demanda, monetização dos déficits públicos, expansão dos créditos às empresas e grandes aumentos salariais. 
O Plano econômico permitiu as transformações institucionais, reformas bancária e tributária e centralizou o poder político e econômico nas mãos dos militares.

\section{MILAGRE ECONÔMICO}

No período compreendido entre 1965 a 1973 houve um intenso crescimento do Produto Interno Bruto brasileiro e da produção industrial, com um crescimento do capital estrangeiro na forma de investimentos diretos. Esse aumento desenfreado do PIB é percebido por muitos e, segundo A. Lacerda , (Economia Brasileira, 2000), "o Brasil foi o pais que mais cresceu o PIB em todo o mundo entre 1970 e 1987". O país, embora subdesenvolvido, apresentou tais resultados devido a política monetária expansiva, na qual o aumento de crédito ao setor privado estimulou a produção para o mercado domestico e internacional. É importante, no entanto, destacar que, enquanto os números indicavam um forte crescimento da economia do país, a concentração de renda e as questões sociais aumentavam desenfreadamente.

No cenário internacional, observou-se a década de 1970 como o momento no qual o capitalismo mundial apresentou os seus gloriosos anos, porque foi uma época onde teve elevadas taxas de crescimento consecutivas graças ao aumento do fluxo de comércio e de capitais financeiros mundiais.

Nos anos 1980, a economia brasileira foi marcada por graves desequilíbrios externos e internos. Logo no início da década, o país enfrentou sua mais grave recessão desde a Grande Depressão fruto da queda da Bolsa de Nova Iorque em 1929. Em 1982, as autoridades econômicas recorreram formalmente ao FMI, em um momento de grande turbulência internacional causada pela moratória da dívida externa mexicana. Ao mesmo tempo em que caía o PIB brasileiro, a inflação começava a alçar um vôo que a transformaria, no final de 1989, em uma hiperinflação.

A chamada década perdida caracterizou-se pela queda nos investimentos e no crescimento do PIB, pelo aumento de déficit público, pelo crescimento das dívidas externa e interna e pela ascensão inflacionária. O PIB apresentara um crescimento médio de 7\% entre 1947 e 1980, caindo para $2 \%$ entre 1981 e 1990 . Em função deste desempenho medíocre do PIB, a renda per capita manteve-se praticamente constante ao longo da década de 1980.

A política econômica adotada no final de 1980 e ao longo de 1981 seguiu os manuais da ortodoxia: controle das despesas públicas e dos gastos das empresas estatais, aumento da arrecadação do Imposto de Renda (IR) e do Imposto Sobre Operações Financeiras (IOF) nas operações de câmbio para exportação; e uma violenta contração da liquidez real e do crédito, com exceção da agricultura, cujo volume de crédito seria expandido.

A moratória mexicana de 1982 tornou ainda mais dramáticas as pressões sobre o balanço de pagamentos. O superávit comercial foi reduzido em função de uma queda nas exportações. Mas as importações caíram, diminuindo o impacto da queda das exportações sobre o déficit comercial.

A recuperação da economia americana a partir de 1984 foi de fundamental importância para a retomada do crescimento da economia brasileira, apoiada no aumento das exportações e no 
crescimento da renda agrícola, em função de uma forte alta nos preços dos produtos primários, que repercutiam em compras de insumos e maquinários.

\section{O BRASIL PÓS DÉCADA DE 70}

O período posterior ao milagre econômico é caracterizado por transformações e crises de ordem econômica e fiscal, além do aumento da dívida externa.

Passadas as grandes mudanças no cenário nacional e internacional da década de 70 , o Brasil ainda colhia os resultados de tais transformações. A crise da dívida externa brasileira nos anos 80 foi decorrência direta do processo de inserção internacional do País. Embora tenha se destacado pela sua magnitude e duração, essa crise foi tão-somente mais uma crise cambial que atingiu a economia brasileira.

O aumento do endividamento foi acelerado a partir do milagre econômico, supostamente financiado pela entrada de recursos externos. A partir do primeiro choque do petróleo e durante o período de implantação do II Plano Nacional de Desenvolvimento, o endividamento aumentou devido ao financiamento dos déficits em transações correntes do País. Após o segundo choque do petróleo e do choque dos juros externos, o crescimento do endividamento passou a se alimentar do aumento dos custos da própria dívida e da deterioração dos termos de troca.

Os dados sobre a evolução da dívida externa do Brasil não deixam dúvidas quanto à importância dos fatores externos na explicação para a escalada do endividamento. O crescente aumento das despesas com o serviço da dívida estava na origem da deterioração das contas internas do País - a chamada crise fiscal do Estado -, no estancamento de seu crescimento, na queda do nível de investimentos e na disparada da inflação. A crise da dívida externa desestruturou profundamente a economia brasileira e conduziu o País à hiperinflação.

\section{COMÉRCIO EXTERIOR BRASILEIRO E NORTE-RIOGRANDENSE}

O cenário internacional nunca foi um ambiente tão favorável pelas economias emergentes como se verifica atualmente. Assim como muitos países, o Brasil busca constantemente garantir, não apenas sua permanência, como também aumentar sua participação na economia mundial. A economia brasileira está em $11^{\circ}$ lugar no ranking mundial com um PIB que, segundo o Instituto Brasileiro de Geografia e Estatística (IBGE) cresce a taxas de 3,7 \% ao ano - índice do ano de 2006.

No que se refere à participação das regiões no cenário mencionado, ainda impera uma forte atuação da economia das regiões Sul e, principalmente Sudeste - esta respondendo com praticamente $50 \%$ do PIB do país, na Balança Comercial. Essa participação é fruto de uma estrutura que apresenta empresas de grande porte e, o que é mais importante, a grande concentração de renda que existe nos grandes centros urbanos. Embora a Região Nordeste apresente infra-estruturas não muito favoráveis no que diz respeito às boas condições de vida de sua população - de uma forma generalizada, ela se caracteriza por ser uma das Regiões com potencial de crescimento econômico, sobretudo, no que diz respeito à geração de energia 
(exploração de recursos naturais - petróleo e derivados, produção alcoleira e biocombustíveis). Há pouco mais de 10 anos a economia nordestina apresentava uma participação no PIB com índices de 4,1\%. Atualmente os números são de aproximadamente $15 \%$, segundo o IBGE.

O Estado do Rio Grande do Norte vem apresentando resultados crescentes, mas pouco expressivo ainda no que respeito à participação nas exportações brasileiras. Embora possa parecer pequena uma atuação de $1 \%$ no PIB brasileiro $-5^{\circ}$ maior do Nordeste, o Estado Potiguar tem uma pauta de exportações distinta e com uma variedade de produtos que lhe rederam um superávit de 130 milhões de Reais no ano passado, segundo a Secretaria de Comércio Exterior (SECEX). A expectativa de crescimento é crescente uma vez que novos investimentos estão previstos com a promessa de alavancar cada vez mais o crescimento econômico.

No que diz respeito a essa nova fase no desenvolvimento norte-riograndense, pode-se citar a construção do Aeroporto Internacional de São Gonçalo do Amarante (Figuras 1 e 2), tido não apenas como uma grande obra, mas também como mais uma oportunidade para os bons resultados na economia do país e do Rio Grande do Norte.

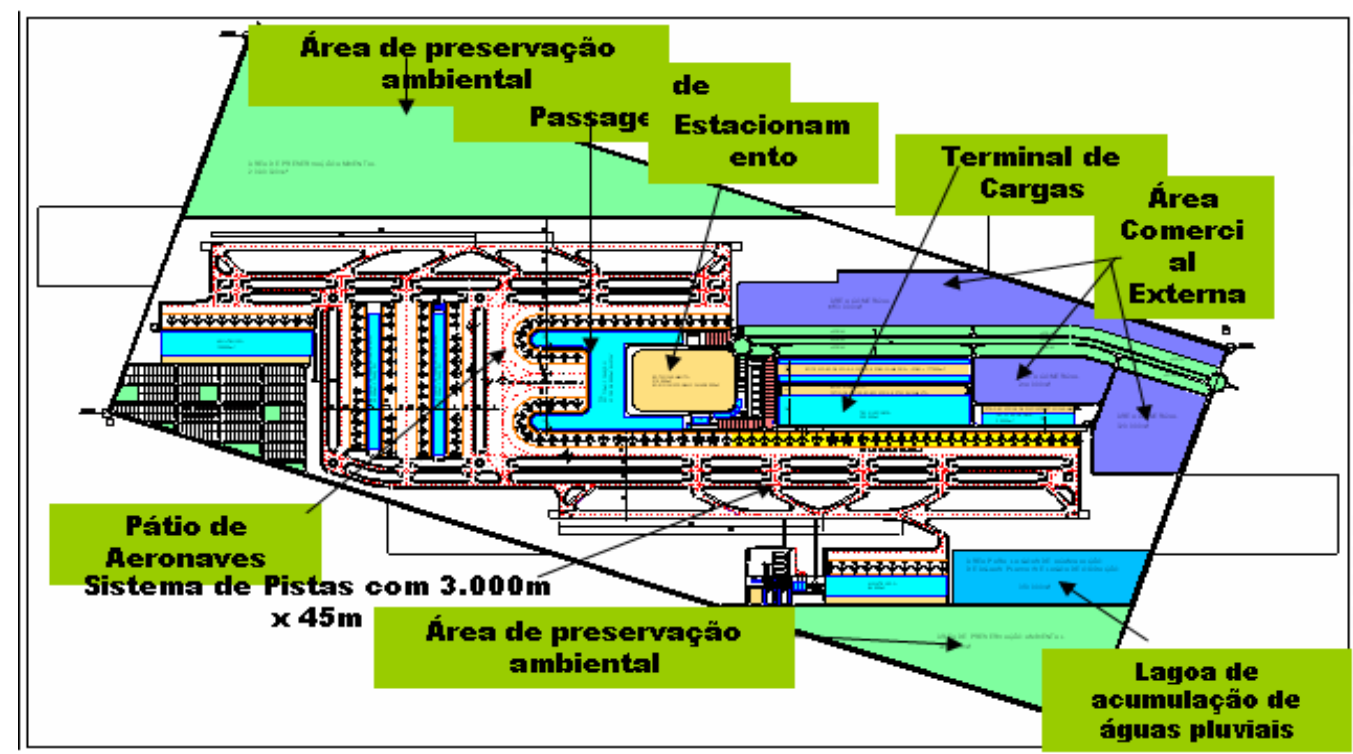

FIGURA 1 - Plano Diretor do Aeroporto de São Gonçalo do Amarente 


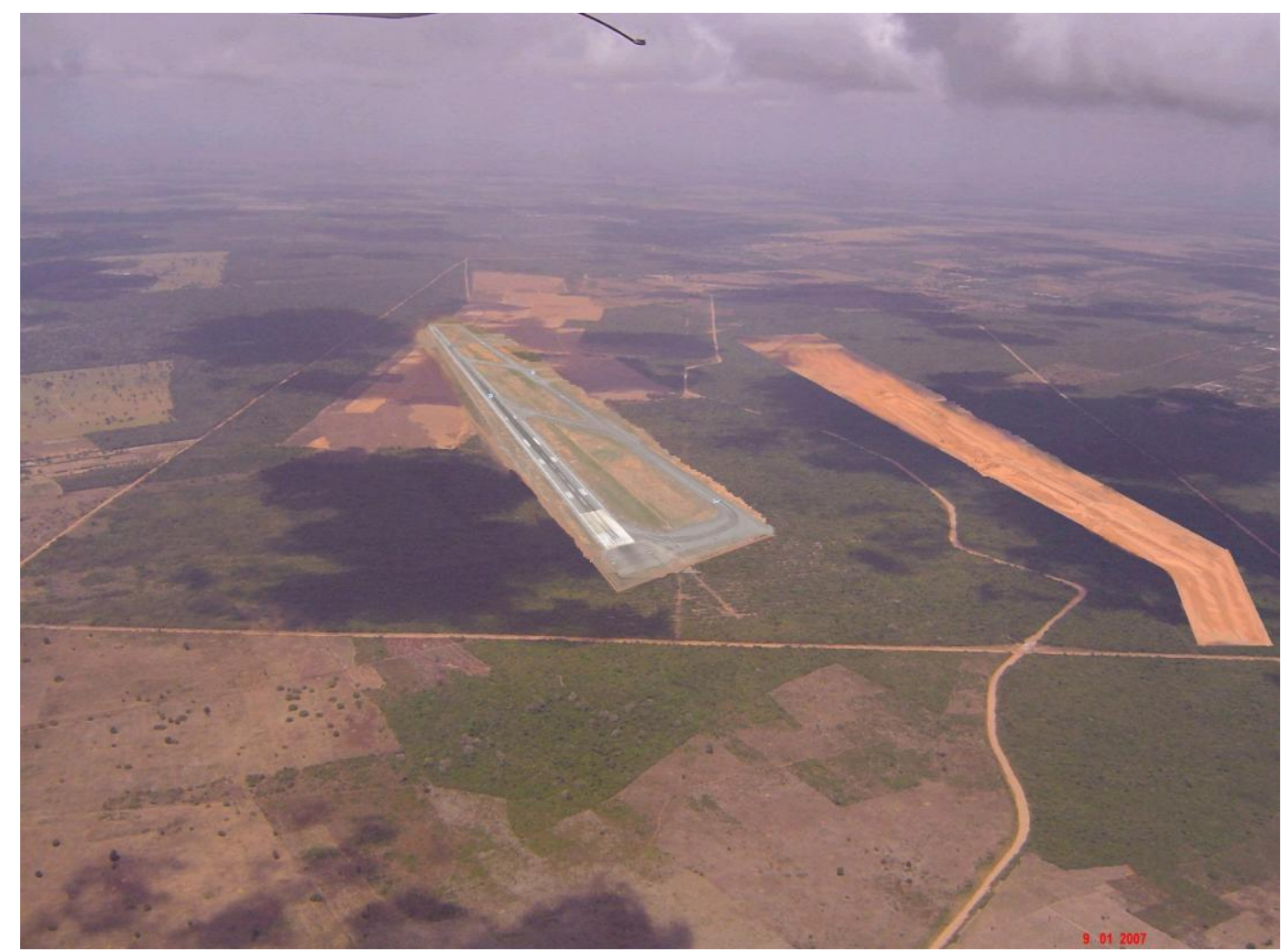

FIGURA 2 - Construção do Aeroporto em andamento.

Segundo o Conselho Metropolitano, grupo da Secretaria de Estado de Planejamento SEPLAN - que estuda e analisa os novos projetos e seus impactos para a região metropolitana de natal, o aeroporto abrirá as portas do Estado para o mundo ao mesmo instante que aumentará o turismo na região. Ele será uma alternativa para reduzir o excesso de demanda para os demais, como Guarulhos (SP) - maior aeroporto em número de passageiros e carga movimentada no país. Segundo a Empresa de Infra-Estrutura Aeroportuária - INFRAERO “o projeto que é orçado em 2 bilhões de reais, permitirá a geração de 180 mil empregos diretos e indiretos além de atrair uma movimentação anual de 10 milhões de turistas internacionais." $\mathrm{O}$ aeroporto que já se encontra em construção, além dos números mencionados anteriormente, será voltado para a movimentação de cargas, as quais, segundo a empresa estatal que administra os aeroportos brasileiros, terão volumes anuais da ordem de 1,5 milhões de toneladas, conforme a Tabela 2 - Construção do Aeroporto Internacional de São Gonçalo do Amarante. Aliando movimentação de mercadorias oriundas do exterior ou a ele destinado, o empreendimento que prevê a circulação de 5 milhões de passageiros por ano em sua primeira etapa - prevista para ser concluída até 2009 (capacidade atual do Aeroporto Internacional Augusto Severo corresponde a 1,5 milhões de passageiros por ano), terá uma capacidade de movimentação de 40 milhões de passageiros por ano e ainda a infra-estrutura com geração de energia - usina para geração de 3 Megawatts de potência, esgotamento sanitário, abastecimento d'água visando, além de atender as necessidades do fluxo de passageiros e cargas, à adequação da área para implantação de indústrias no entorno do aeroporto. 
Tabela 2 - Construção do Aeroporto Internacional de São Gonçalo do Amarante.

\begin{tabular}{|c|c|c|}
\hline $\begin{array}{c}\text { AEROPORTO } \\
\text { INTERNACIONAL DE SÃO } \\
\text { GONÇALO }\end{array}$ & $\mathbf{1}^{\mathbf{a}}$ FASE & $\begin{array}{c}\mathbf{2}^{\mathbf{a}} \text { FASE (CONCLUSÃO } \\
\text { DO PROJETO) }\end{array}$ \\
\hline Capacidade Final & $\begin{array}{c}05 \text { milhões de } \\
\text { passageiros }\end{array}$ & 40 milhões de passageiros \\
\hline Custo Estimado & $\mathrm{R} \$ 500$ milhões & $\mathrm{R} \$ 2,1$ BILHÕES \\
\hline $\begin{array}{c}\text { Geração de Emprego (diretos e } \\
\text { indiretos) }\end{array}$ & $\begin{array}{c}25 \text { mil posições de } \\
\text { trabalho }\end{array}$ & $\begin{array}{c}180 \text { mil posições de } \\
\text { trabalho }\end{array}$ \\
\hline $\begin{array}{c}\text { Fluxo de Passageiros Estrangeiros } \\
\text { internacionais/ano } \\
\text { inthano de turistas }\end{array}$ & $\begin{array}{c}10 \text { milhões de turistas } \\
\text { internacionais/ano }\end{array}$ \\
\hline Volume de Carga Movimentada & $\begin{array}{c}1 / 2 \text { milhão toneladas de } \\
\text { carga/ano }\end{array}$ & $\begin{array}{c}1,5 \text { milhão de toneladas de } \\
\text { carga/ano }\end{array}$ \\
\hline
\end{tabular}

Fonte: INFRAERO

Abrindo às portas da economia do Estado para o mundo e promovendo a chegada de novos investimentos, o Aeroporto concretiza a implantação do que, segundo o Conselho Metropolitano, é denominado "aerotrópolis" - um arranjo produtivo que se constitui tomando como base o aeroporto e uma série de fatores que o tornam o centro de um complexo urbano (região metropolitana). O planejamento e a instalação dessa infra-estrutura que demanda facilitar o tráfego da região (construção de vias de trânsito rápido - freeway, passagens de nível, túneis, viadutos e transportes de superfície), assim como a oferta de recursos naturais (energia), tornará essa área propícia à implantação de uma Área Econômica Especial (ZPE) que funcionará como núcleo de um complexo produtivo.

\section{FORMAS DE GESTÃO DE MERCADOS}

A economia mundial e dinamismo do Comércio Internacional são elementos de grande importância para o gerenciamento dos mercados. No sentido de obter cada vez mais os resultados satisfatórios, os países adotam mecanismos que estimulam o crescimento de suas economias, tais como incentivo às exportações, reformas político-econômicas, reformas físcal e tributária, além de criarem novas tecnologias.

Interagem dessa maneiras, os mercados mais conservadores e distintos, no aspecto político, conseguem reduzir as diferenças na ótica econômica - abrindo a economia doméstica ao cenário internacional, embora mantenham o tradicionalismo político. Nesse sentido, podemos observar a economia chinesa e sua participação no comércio internacional assim como as suas zonas econômicas especiais (ZEE's - correspondente às ZPEs). 


\section{A CHINA E A CRIAÇÃO DAS ZPES}

A queda do Comunismo7 no Leste Europeu e na União Soviética nos anos 90, levou a estagnação e a decadência econômica para esses mercados. Porém, na China, mesmo sobre o escudo desse, sistema, sua economia tem passado por transformações de abertura controlada desde a década de 1970 que tem gerado um crescimento econômico apreciável a todas as nações do mundo e uma maior integração deste país com o mercado global. O país adotou políticas de modernização em todos os sentidos - indústria, agricultura, ciência e tecnologia e Forças Armadas. Além disso, deu espaço à criação de Zonas Econômicas Especiais (ZEEs), também denominadas ZPEs, que foram abertas a investimentos estrangeiros onde se incentivou a propriedade privada. O objetivo das ZPEs é atrair investimentos estrangeiros para as cidades exportadoras do litoral oferecendo mão-de-obra que resulta em elevadas taxas de crescimento, com média de até $9,3 \%$ anual, e uma invasão de produtos chineses por todo o mundo.

O processo de abertura econômica do mercado chinês vem sendo agitado desde o final da década de 70, mais precisamente após as mudanças no cenário político (Terceira Sessão Plenária do XI Comitê Central do Partido Comunista da China). Naquele momento o país entrou numa nova etapa de seu desenvolvimento. A política do Estado chinês concentrou esforços na formação e aplicação de uma reforma seguida de uma abertura completa ao mundo exterior.

Mais tarde, durante os anos 80, a China estabeleceu Zonas Econômicas Especiais (ZEEs) (Shenzhen, Zhuhai e Shantou na Província de Guangdong, Xiamen na província de Fujian, e toda a ilha de Hainan), assim como cidades e áreas litorâneas abertas, além das zonas interiores e litorais abertas econômicas e tecnológicas. O estabelecimento das ZPEs na China tinha o objeto de aprofundar o processo de abertura da economia ao comércio internacional e estimular o desenvolvimento econômico dentro do país. A Tabela 3 - Apresentação das ZPEs Chinesas mostra tais áreas especiais e suas características.

Tabela 3 - Apresentação das ZPEs Chinesas

\begin{tabular}{|l|c|c|c|}
\hline NOME & $\begin{array}{c}\text { ÁREA } \\
\left(\mathbf{K m}^{\mathbf{2}}\right)\end{array}$ & $\begin{array}{c}\text { MÉDIA VOLUME NEGÓCIOS / } \\
\text { US\$ / BILHÕES / MÊS }\end{array}$ & ANO DE CRIAÇÃO \\
\hline Shenzhen & 327,5 & 5,0 & 1980 \\
\hline Zhuhai & 121 & 1,3 & 1980 \\
\hline Xiamen & 131 & 1,1 & 1980 \\
\hline Shantou & 52,6 & 0,4 & 1980 \\
\hline Hainan & 34 & 0,1 & 1988 \\
\hline
\end{tabular}

Fonte: Rogério Haesbaert - China Entre o Oriente e o Ocidente

\footnotetext{
${ }^{7}$ Comunismo é um sistema econômico que nega a propriedade privada dos meios de produção. Num sistema comunista os meios de produção são de propriedade comum a todos os cidadãos e são controlados por seus trabalhadores. Sob tal sistema, o Estado não tem necessidade de existir e é extinto (Wikipédia).
} 
Em 1984, a China possibilitou a abertura de 14 cidades litorâneas aos investimentos internacionais - Dalian, Qinghuangdao, Tianjin, Yantai, Qingdao, Lianyungang, Nantong, Shanghai, Ningbo, Wenzhou, Fuzhou, Guangzhou, Zhanjiag e Beihai.

A partir do final da década de 80, a abertura econômica ao mercado estrangeiro foi estendida às áreas fronteiriças do país, às áreas ao longo do Rio Yang-Tze e às áreas interiores. $\mathrm{O}$ Estado decidiu transformar a Ilha de Hainan na maior zona econômica especial da China e dar mais um passo no desenvolvimento das outras quatro ZPEs.

A abertura dessas zonas constituiu uma base sólida para os esforços chineses na condução do desenvolvimento econômico do país.

No final da década de 90 e início do século ocorreu o boom das exportações chinesas com o crescimento impressionante de taxas anuais de até $40 \%$, fruto do esforço para o crescimento econômico no cenário doméstico, mencionado anteriormente, que levou a índice de $8,1 \%$ do Produto Interno Bruto (PIB) chinês. É importante ressaltar que parte desse bom desempenho na balança comercial chinesa está conjugada às fases anteriores dos ciclos econômicos dos principais clientes da China: os EUA, o Japão, a União Européia e, cada vez mais, a própria Ásia Oriental.

É importante mencionar que esse crescimento nas vendas externas da China gerou uma resistência de sua economia diante da crise asiática iniciada em 1997.

Todas essas mudanças ocorridas, principalmente as de ordem política, serviram para ancorar o crescimento econômico, que com o início das reformas, levou a China a crescimentos imediatos médios de 9,3\%.a.a. entre 1993 e 2002, segundo o Fundo Monetário Internacional (FMI).

A partir de 2003, enquanto a economia mundial crescia a menos de $3 \%$, o governo chinês anunciou um crescimento na ordem de 9,1\%. Esse índice reduziu para $7 \%$ durante o período de 2004-2005 que, embora menor se comparado à taxa anterior, ainda evidencia um expressivo crescimento econômico. Como se trata de um país de grandes extensões territoriais, atualmente, a China tem como política o fortalecimento integral, principalmente da região Oeste, objetivando harmonizar o desenvolvimento do país orientando pela Costa Leste, considerada a área mais desenvolvida.

Traçando-se um comparativo entre o crescimento da economia brasileira e a chinesa, observamos a seguinte Tabela 4 - Comparação do Crescimento Real do PIB - Variação Anual (\%):

Tabela 4 - Comparação do Crescimento Real do PIB - Variação Anual (\%)

\begin{tabular}{|c|c|c|c|c|c|c|c|c|c|c|}
\hline PAÍS & $\mathbf{1 9 9 3}$ & $\mathbf{1 9 9 4}$ & $\mathbf{1 9 9 5}$ & $\mathbf{1 9 9 6}$ & $\mathbf{1 9 9 7}$ & $\mathbf{1 9 9 8}$ & $\mathbf{1 9 9 9}$ & $\mathbf{2 0 0 0}$ & $\mathbf{2 0 0 1}$ & $\mathbf{2 0 0 2}$ \\
\hline CHINA & 13,5 & 12,6 & 10,5 & 9,6 & 8,8 & 7,8 & 7,1 & 8,0 & 7,3 & 7,5 \\
\hline BRASIL & 4,9 & 5,9 & 4,2 & 2,7 & 3,3 & 0,2 & 0,8 & 4,4 & 1,4 & 1,5 \\
\hline
\end{tabular}

Fonte: FMI / World Economic Autlook.

As ZPEs ou, como são chamadas na china, ZEEs foram grandes propulsoras da abertura econômica de 1979, que é a base experimental para as reformas econômicas e a migração de 
uma economia socialista e fechada para uma mais aberta ao capitalismo. Essas transformações tinham o objetivo de desenvolver regiões litorâneas, atrair capital estrangeiro, elaborar produtos variados para os mais diversos setores com valor agregado com mão-de-obra barata e qualificada. Ao mesmo tempo em que as reformas tornaram as ZPEs carro chefe no processo de crescimento econômico chinês, elas voltavam o país para o mercado externo o que fazia da China após década de 80 diferente daquela antes das mudanças ocorridas a partir de 1979.

\section{POLÍTICAS INDUSTRIAIS E DE EXPORTAÇÕES DO BRASIL}

A competição internacional a qual se faz tanta referência é uma realidade vivenciada por todas as nações que atuam no cenário mundial. Nesse ambiente, marcado pela instabilidade, as relações comerciais são desempenhadas mediante obstáculos - barreiras operacionais, e políticas favoráveis - investimentos.

\section{BARREIRAS À EXPORTAÇÃO E INVESTIMENTOS}

Em praticamente todos continentes do mundo há políticas que estimulem o desenvolvimento adotando novas estratégias, tais como o fim de barreiras sanitárias e fiscais, que promovam a abertura comercial. Segundo Kelleher e Kavanagh (1996), "a remoção de barreiras comerciais, a eliminação de preços para alocar recursos" são definidas como as estratégias adotadas por tais políticas.

As relações comerciais são orientadas por fatores relacionados ao nível de consumo - país populoso é geralmente muito visado, a cultura - o grau de facilidade de penetração em mercados depende do nível de abertura político-social, e fatores tecnológicos e econômicos a disponibilidade de infra-estrutura é um atrativo para muitos investidores alocarem recursos. Partindo-se desses elementos, Kellerher e Kavanagh (2006) admitem que "o Brasil é muito atraente para se investir, pois, além de dispor de um quadro demográfico favorável (mais de 180 milhões de habitantes), estimula a formação do Mercosul que, com características sócioculturais muito próximas às brasileiras, aumenta ainda mais o mercado potencial".

Além das políticas mencionadas, criação de Zonas de Processamento de Exportação é mais uma alternativa que viabilize o desenvolvimento industrial e a inserção do país no mercado internacional.

\section{REGIMES ADUANEIROS ESPECIAIS}

Devido à dinâmica do comércio exterior, houve a necessidade de se criar mecanismos que permitissem a entrada ou a saída de mercadorias do território aduaneiro com suspensão ou isenção de tributos. Esses mecanismos são denominados Regimes Aduaneiros Especiais. Conforme a Secretaria da Receita Federal (SRF), os Regimes Aduaneiros Especiais são dispostos da seguinte maneira: 


\begin{abstract}
"Os regimes aduaneiros especiais, em suas mais variadas espécies, apresentam como característica comum a exceção à regra geral de aplicação de impostos exigidos na importação de bens estrangeiros ou na exportação de bens nacionais (regimes comuns de importação e de exportação), além da possibilidade de tratamento diferenciado nos controles aduaneiros.

A importância econômica dos regimes aduaneiros especiais não se restringe à desoneração de impostos na importação de bens estrangeiros destinados a industrialização no País de produto final a ser exportado, com seus efeitos positivos sobre a balança comercial decorrentes de maior competitividade do produto nacional no mercado internacional.

A utilização de regimes aduaneiros especiais, tendo em vista a natureza de cada uma de suas espécies e respectivas aplicações, também tem outros efeitos importantes na atividade econômica, tais como:

a) o armazenamento, no País, de mercadorias estrangeiras, permitindo ao importador manutenção de estoques estratégicos tributos por ocasião do despacho para consumo;

b) realização de feiras e exposições comerciais; $e$

c) o transporte de mercadorias estrangeiras com suspensão sob controle aduaneiro.

"Afora isso, ao permitir a realização de eventos de natureza científica, com a utilização de bens estrangeiros, os regimes possibilitam maior integração do País com o exterior."
\end{abstract}

Entende-se dessa maneira que o Regime é um conjunto de regras que estabelecem certa conduta obrigatória. É método, sistema ou forma de um governo agir. Logo, chamamos de regime aduaneiro ao tratamento tributário e administrativo aplicáveis às mercadorias submetidas a controle aduaneiro, segundo a natureza e objetivos da operação, e de acordo com as leis e regulamentos aduaneiros. Os Regimes são de Admissão Temporária, Áreas de Livre Comércio, Depósito Afiançado, Depósito Alfandegado Certificado, Depósito Especial, Depósito Franco, Drawback, Entreposto , Aduaneiro, Exportação Temporária, Exportação Temporária para Aperfeiçoamento Passivo, Loja Franca, Recof, Recom, Repetro, Repex e o Trânsito Aduaneiro.

\title{
ADMISSÃO TEMPORÁRIA
}

É o regime que permite a importação de bens que devam permanecer no País durante prazo fixado, com suspensão de tributos, retornando ao exterior, sem sofrer modificações que lhes confiram nova individualidade.

Esse regime suspensivo tem como objetivo favorecer a importação de bens para atender a interesses nacionais de ordem econômica, científica, técnica, social e cultural desde que respeitadas as condições básicas para sua aplicação, tais como: constituição das obrigações fiscais em termo de responsabilidade; utilização dos bens dentro do prazo fixado e exclusivamente nos fins previstos; identificação dos bens; e importação sem cobertura cambial.

O Secretário da Receita Federal tem autorização para estabelecer outros termos, limites e condições para a concessão do regime de admissão temporária, bem como estabelecer a sua aplicação a outros casos além dos previstos no Regulamento Aduaneiro. Poderão ser 
admitidos no regime, entre outros, bens destinados a: exposições artísticas, culturais e científicas; exposições e feiras comerciais ou industriais; competições ou exibições desportivas; servir de modelo industrial; testes, conserto, reparo ou restauração; veículos de turistas estrangeiros; veículos de brasileiros radicados no exterior, que ingressem no País em caráter temporário; recipientes, envoltórios e embalagens; aparelhos para teste e controle; máquinas, equipamentos, aparelhos e instrumentos, para demonstração em estabelecimentos de ensino, pesquisa e médico-hospitalares; moldes, matrizes e chapas; e outros, definidos pela Secretaria de Receita Federal.

\section{ÁREAS DE LIVRE COMÉRCIO}

Esses espaços delimitados por lei constituem uma tipologia de regime aduaneiro especial que permite a livre circulação de mercadorias e pessoas sem restrições. A funcionalidade é semelhante às ZPEs e as Zonas Francas nas quais as importações de bens não precisam de permanência no País por um prazo determinado para se garantir a suspensão de tributos. Além de ser um tratamento que requer uma lei específica que o crie, esse regime tem características distintas uns dos outros no que diz respeito à região na qual está inserida e a natureza das atividades econômicas ali desenvolvidas.

\section{DEPÓSITO AFIANÇADO - DAF}

O DAF, como também é denominado o Regime Aduaneiro Especial de Depósito Afiançado, permite a estocagem, com suspensão do pagamento de impostos, de materiais importados sem cobertura cambial, destinados à manutenção e ao reparo de embarcação ou de aeronave pertencentes a empresa autorizada a operar no transporte comercial internacional, e utilizadas nessa atividade.

A autorização para empresa estrangeira operar no regime, pela autoridade aduaneira, é condicionada a previsão em ato internacional firmado pelo Brasil, ou a que seja comprovada a existência de reciprocidade de tratamento.

O prazo de permanência dos materiais no regime será de até 05 anos, a contar da data de desembaraço aduaneiro para admissão. $O$ controle aduaneiro de entrada, da permanência e da saída de mercadoria será efetuado mediante processo informatizado ${ }^{8}$.

\section{DEPÓSITO ALFANDEGADO CERTIFICADO - DAC}

O regime de Depósito Alfandegado Certificado permite considerar exportada, para todos os efeitos fiscais, creditícios e cambiais, a mercadoria nacional depositada em recinto alfandegado, vendida a pessoa sediada no exterior, mediante contrato de entrega no território nacional e à ordem do adquirente. O regime será operado, mediante autorização da SRF, em recinto alfandegado de uso público.

\footnotetext{
${ }^{8}$ O Sistema Integrado de Comércio Exterior (SISCOMEX) por meio do PREVINE, software que cumpre todas as exigências da Refeita Federal no que se refere a Sistemas de Controle Informatizado, controla a entrada (importações e aquisições no mercado interno), permanência e saída de mercadorias, de registro e apuração de créditos tributários devidos, extintos ou com exigibilidade suspensa.
} 
Para utilização do regime, deve-se cumprir as seguintes exigências: a mercadoria seja vendida mediante um contrato DUB (Delivered Under Customs Bond / Entregue ou liberado sob custódia da alfândega); a operação deverá estar inscrita em um Registro de Exportação - RE do SISCOMEX; o depósito da mercadoria deverá ser feito pelo vendedor, à ordem do comprador, em local autorizado pela Secretaria da Receita Federal; e a mercadoria deverá ser conferida e desembaraçada para exportação.

O Regime será operado em recinto alfandegado de uso público ou em instalação portuária de uso privativo misto autorizados pelo Superintendente Regional da Receita Federal (SRRF) com jurisdição sobre o local, mediante a expedição de Ato Declaratório Executivo (ADE).

A autorização para operar o regime será concedida a requerimento do administrador do recinto, apresentado ao titular da unidade da SRF com jurisdição sobre o local, contendo, pelo menos: a especificação dos gêneros de cargas a serem armazenadas ao amparo do regime geral, frigorificada ou a granel; planta de locação, baixa e de corte da área a ser utilizada no recinto para depósito de mercadoria admitida no regime; e a delimitação, no recinto, de área destinada exclusivamente à movimentação e armazenagem de mercadoria estrangeira ou desnacionalizada.

As mercadorias poderão permanecer no regime pelo prazo de 1 ano, podendo ser prorrogável por mais 1 ano, contado da emissão do conhecimento de depósito alfandegado.

No DAC existe ainda a possibilidade de extinção de sua aplicabilidade que ocorrer mediante: comprovação do efetivo embarque ou da transposição da fronteira, da mercadoria destinada ao exterior; despacho para consumo; ou a transferência para outros regimes aduaneiros: drawback; admissão temporária, inclusive para as atividades de pesquisa e exploração de petróleo e seus derivados (Repetro); loja franca ou entreposto aduaneiro.

\section{DEPÓSITO ESPECIAL - DE}

O Regime Aduaneiro Especial de Depósito Especial (DE) é o que permite a estocagem, com suspensão do pagamento de impostos, de partes, peças, componentes e materiais de reposição ou manutenção, para veículos, máquinas, equipamentos, aparelhos e instrumentos, estrangeiros, nacionalizados ou não, empregados nas atividades de: transporte; apoio à produção agrícola; construção e manutenção de rodovias, ferrovias, portos, aeroportos, barragens e serviços afins; pesquisa, prospecção e exploração de recursos minerais; geração e transmissão de som e imagem; diagnose, cirurgia, terapia e pesquisa médicas, realizadas por hospitais, clínicas de saúde e laboratórios; geração, transmissão e distribuição de energia elétrica; e análise e pesquisa científica, realizadas por laboratórios.

As mercadorias admitidas no DE poderão ter as seguintes destinações: reexportação; exportação, inclusive quando as mercadorias forem aplicadas em serviços de reparo ou manutenção de veículos, máquinas, aparelhos e equipamentos estrangeiros, de passagem pelo país; transferência para outro regime especial ou aplicado em áreas especiais; despacho para consumo; e destruição, com autorização do consignante, às expensas do beneficiário. O prazo de permanência da mercadoria no regime é de 5 anos, a contar do desembaraço para admissão. 
É importante mencionar as condições para habilitação. Para que uma empresa possa estar autorizada a utilizar o regime, ela deve cumprir os seguintes critérios: possuir certidão negativa de débitos relativos a tributos e condições administrados pela SRF; possuir o Registro de Exportador - RE, Importador - RI, ou Exportador e Importador - REI - na SRF; e exercer atividades relacionadas a importação em consignação de partes, peças, componentes e materiais de reposição ou manutenção para máquinas, equipamentos, aparelhos e instrumentos, estrangeiros, nacionalizados ou não, empregados em tais atividades.

\section{DEPÓSITO FRANCO}

É o regime que permite, em recinto alfandegado, a armazenagem de mercadoria estrangeira para atender ao fluxo comercial de países limítrofes com terceiros países. O regime de depósito franco será concedido somente quando autorizado em acordo ou convênio internacional firmado pelo Brasil.

As operações deste regime são fiscalizadas e controladas pelo órgão jurisdicionante da Receita Federal.

\section{DRAWBACK}

O Regime Aduaneiro Especial de Drawback consiste na suspensão ou eliminação de tributos incidentes sobre insumos importados para utilização em produto exportado. $\mathrm{O}$ mecanismo funciona como um incentivo às exportações, pois reduz os custos de produção de produtos exportáveis, tornando-os mais competitivos no mercado internacional. Existem três modalidades de drawback: isenção, suspensão e restituição de tributos.

A primeira modalidade consiste na isenção dos tributos incidentes na importação de mercadoria, em quantidade e qualidade equivalentes, destinada à reposição de outra importada anteriormente, com pagamento de tributos, e utilizada na industrialização de produto exportado.

A segunda, na suspensão dos tributos incidentes na importação de mercadoria a ser utilizada na industrialização de produto que deve ser exportado.

A terceira trata da restituição de tributos pagos na importação de insumo importado utilizado em produto exportado. O drawback de restituição praticamente não é mais utilizado. $\mathrm{O}$ instrumento de incentivo à exportação em exame compreende, basicamente, as modalidades de isenção e suspensão.

Tem direito ao incentivo do Drawback as empresas que realizam operações de industrialização sobre peças, componentes, matérias-primas e/ou outros insumos importados, fabricando com eles produtos destinados à exportação. Pode habilitar-se também a empresa que importa peças, componentes, matérias-primas e/ou outros insumos para fabricar produtos intermediários, ou seja, produtos que integram um outro produto, fabricado por outra empresa, destinado à exportação. É o caso, por exemplo, do fabricante de pneus, que os fornece à indústria automobilística, que por sua vez os exporta montados em seus automóveis. 
O Regime de Drawback pode ser concedido ainda à empresa de fins comerciais. Nesse caso, a mercadoria deverá ser industrializada sob encomenda em estabelecimento industrial, por conta e ordem da beneficiária do Regime de Drawback e posteriormente exportada.

\section{ENTREPOSTO ADUANEIRO}

O regime de Entreposto Aduaneiro permite, na importação e na exportação, o depósito de mercadoria, em local determinado, com suspensão do pagamento de tributos e sob controle fiscal. As mercadorias admitidas no regime de entreposto aduaneiro, na importação e na exportação, poderão ser submetidas às seguintes operações: exposição, demonstração e teste de funcionamento; industrialização; e manutenção ou reparo.

As mercadorias armazenadas em recinto alfandegado de uso público sob o regime de entreposto aduaneiro na importação ou na exportação poderão ser objeto: de etiquetagem e marcação, para atender a exigências do comprador estrangeiro; de exposição, demonstração e teste de funcionamento; das operações de industrialização. Quanto a essas operações, elas podem ser: acondicionamento ou recondicionamento; montagem; beneficiamento; renovação ou recondicionamento das partes, peças e outros materiais nas condições citadas acima; e transformação, no caso de preparo de alimentos para consumo a bordo de aeronaves e embarcações utilizadas no transporte comercial internacional ou destinados a exportação.

O recinto alfandegado credenciado para a realização de atividades de industrialização receberá as seguintes denominações: aeroporto industrial, se localizado em aeroporto; plataforma portuária industrial, se localizada em porto organizado ou instalação portuária de uso público; ou porto seco industrial, se localizado em Estação Aduaneira de Interior - EADI.

No que se refere a admissão no Regime para armazenagem dos bens, é importante destacar que a autorização depende se é aeroporto, porto ou porto seco.

Os bens que se destinam a armazenagem em aeroporto no Regime são: as partes, peças e outros materiais de reposição, manutenção ou reparo de aeronaves, e de equipamentos e instrumentos de uso aeronáutico; provisões de bordo de aeronaves utilizadas no transporte comercial internacional; e quaisquer outros importados e consignados a pessoa jurídica estabelecida no País, ou destinados a exportação, que atendam às condições para admissão no regime.

Quanto aos bens armazenáveis nos portos organizados - incluídas as instalações portuárias de uso público, podem ser: as partes, peças e outros materiais de reposição, manutenção ou reparo de embarcações, e de equipamentos e instrumentos de uso náutico; provisões de bordo de embarcações utilizadas no transporte comercial internacional; bens destinados a manutenção, substituição ou reparo de cabos submarinos de comunicação; e quaisquer outros importados e consignados a pessoa jurídica estabelecida no País ou destinadas a exportação, que atendam às condições para admissão no regime.

Aos portos secos, os bens enquadrados no Regime devem estar relacionados da seguinte forma: ser parte, peça e outros materiais de reposição, manutenção ou reparo de aeronaves e embarcações; parte, peça e outros materiais de reposição, manutenção ou reparo de outros veículos, bem assim de máquinas, equipamentos, aparelhos e instrumentos; quaisquer outros 
importados e consignados a pessoa física ou jurídica, domiciliada ou estabelecida no País, ou destinados a exportação, que atendam às condições para admissão no regime.

\section{EXPORTAÇÃO TEMPORÁRIA}

O Regime Aduaneiro Especial de Exportação Temporária permite a saída, do País, com suspensão de imposto de exportação, de mercadoria nacional ou nacionalizada, condicionada à reimportação em prazo determinado, no mesmo estado em que foi exportada.

O regime facilita a saída dos bens que vão ao exterior para exposições, feiras, competições, testes, promoções, reparos, consertos, restaurações, ou em auxílio ou apoio a pessoa que viaja ao exterior deles necessitando para o exercício de suas atividades profissionais ou de lazer. A Característica mais marcante desse regime é o benefício oferecido ao exportador, uma que não haverá a ocorrência do fato gerador do imposto de importação e do imposto sobre produtos industrializados, quando do reingresso das mercadorias no País.

A exportação temporária deve operar-se com o objetivo definido e por prazo determinado, assegurada a suspensão do imposto de exportação, quando devido, mediante assinatura de Termo de Responsabilidade, dispensados depósito, caução ou fiança.

O regime se aplica a bens destinados a: feiras, exposições, congressos ou outros eventos científicos ou técnicos; espetáculos, exposições e outros eventos artísticos ou culturais; competições ou exibições esportivas; feiras ou exposições comerciais ou industriais; promoção comercial, inclusive amostras sem destinação comercial e mostruários de representantes comerciais; execução de contrato de arrendamento operacional, de aluguel, de empréstimo ou de prestação de serviços, no exterior; prestação de assistência técnica a produtos exportados, em virtude de termos de garantia; atividades de interesse da agropecuária, inclusive animais para feiras ou exposições, pastoreio, trabalho, cobertura ou cuidado da medicina veterinária; e emprego militar e apoio logístico às tropas brasileiras designadas para integrar força de paz em território estrangeiro.

\section{EXPORTAÇÃO TEMPORÁRIA PARA APERFEIÇOAMENTO PASSIVO}

O Regime Aduaneiro Especial de Exportação Temporária para Aperfeiçoamento Passivo permite a saída, do País, por tempo determinado (mão superior a 1 ano contado a partir da data de admissão no regime), de mercadoria nacional ou nacionalizada, para ser submetida a operação de transformação, elaboração, beneficiamento ou montagem, no exterior, e sua reimportação, na forma do produto resultante dessas operações, com pagamento do imposto incidente sobre o valor agregado.

\section{LOJA FRANCA}

Permite a estabelecimento instalado em zona primária de porto ou de aeroporto alfandegado vender mercadoria nacional ou estrangeira a passageiro em viagem internacional, contra pagamento em cheque de viagem ou em moeda estrangeira conversível. 
O Regime Aduaneiro Especial de Loja Franca permite a estabelecimento instalado em zona primária de porto ou de aeroporto alfandegado vender mercadoria nacional ou estrangeira a passageiro em viagem internacional, contra pagamento em cheque de viagem ou em moeda estrangeira conversível.

A autorização para instalar e operar loja franca será outorgada a empresa selecionada mediante concorrência pública e habilitação junto a SRF. O processo licitatório é realizado conjuntamente com a entidade administradora do porto ou aeroporto. As mercadorias permanecerão depositadas, com suspensão de tributos e sob controle fiscal, convertendo-se a suspensão em isenção, por ocasião da venda.

Somente poderão adquirir mercadorias neste estabelecimento: tripulantes e passageiros em viagem internacional; missões diplomáticas, repartições consulares, representações de organismos internacionais de caráter permanente e a seus integrantes e assemelhados; e empresas de navegação aérea ou marítima, para uso ou consumo de bordo de embarcações ou aeronaves, de bandeira estrangeira, aportadas no País.

\section{RECOF}

O Regime Aduaneiro de Entreposto Industrial Sob Controle Informatizado - RECOF - é um Regime Especial criado pela Receita Federal que permite, dentre outras coisas, que os insumos da produção sejam importados com suspensão de II, IPI e PIS/PASEP e Cofins. Permite ainda que os insumos adquiridos no mercado interno tenham suspensão de IPI.

A característica fundamental do RECOF é que se a produção for direcionada à exportação, a empresa simplesmente fica isenta do recolhimento de tributos que estavam suspensos. Se a produção for direcionada para a venda no mercado local, os impostos suspensos relativos aos produtos importados deverão ser recolhidos apenas no quinto dia útil do mês seguinte ao faturamento do produto acabado. Outro ponto importante é que uma empresa importadora pode transferir seu produto industrializado com insumos admitidos pelo RECOF para uma outra empresa habilitada, mantendo os impostos suspensos até que esta última destine o seu produto final.

Para se habilitar ao RECOF a empresa deve ser indústria de produtos Informática e telecomunicações; semicondutores e de componentes de alta tecnologia para informática e telecomunicações; industrialização e prestação de serviços no setor aeronáutico; e do segmento automotivo. Além disso, ela deve está registrada no SISCOMEX, ter idoneidade fiscal; possuir patrimônio líquido igual ou superior a $\mathrm{R}$ \$ 25 milhões (Industrial), $\mathrm{R}$ \$ 5 milhões (Prestadora de Serviços); possuir autorização para exercício da atividade, expedida pela autoridade aeronáutica competente quando for o caso; assumir compromisso de limite mínimo de exportações, de acordo com a modalidade de seus negócios; e industrializar pelo menos $80 \%$ das mercadorias estrangeiras admitidas no regime.

\section{RECOM}

O Regime Aduaneiro Especial de Importação de Insumos Destinados a Industrialização por encomenda de produtos classificados nas posições 8701 a 8705 da Nomenclatura Comum do 
Mercosul (NCM) é o que permite a importação de chassis, carroçarias, peças, partes, componentes e acessórios, com suspensão do pagamento do imposto sobre produtos industrializados.

O regime será aplicado exclusivamente às importações realizadas por conta e ordem de pessoa jurídica encomendante domiciliada no exterior. No RECOM, a importação dar-se-á com pagamento somente do imposto incidente sobre os insumos, e com suspensão do IPI, que será concedida pelo prazo improrrogável de um ano, contado do desembaraço aduaneiro, no curso do qual deverão ser realizadas a industrialização e a destinação dos produtos resultantes. Os estabelecimentos executores ficarão sujeitos ao recolhimento do IPI suspenso caso destinem os produtos recebidos

com suspensão a fim diverso do previsto no regime aduaneiro.

Os produtos resultantes da industrialização por encomenda terão os seguintes tratamentos tributários: quando destinados ao exterior, resolve-se a suspensão do pagamento do imposto sobre produtos industrializados incidentes na importação e na aquisição, no mercado interno, dos insumos neles empregados; e quando destinados ao mercado interno, serão remetidos obrigatoriamente a empresa comercial atacadista, controlada, direta ou indiretamente, pela pessoa jurídica encomendante domiciliada no exterior, por conta e ordem desta, com suspensão do pagamento do imposto sobre produtos industrializados.

A suspensão do IPI dar-se-á pelo prazo improrrogável de um ano, contado da saída do produto do estabelecimento executor, findo o qual, se não recolhido o imposto, o estabelecimento comercial atacadista responderá pelo pagamento do IPI devido, com os acréscimos legais. O IPI incidente sobre os produtos resultantes (veículos) será devido na saída do estabelecimento comercial atacadista equiparado a industrial, constituindo base de cálculo o respectivo preço da operação.

O regime somente se aplica aos casos em que os pagamentos decorrentes da exportação de serviços pelo executor representem ingresso de divisas. $O$ ingresso no regime especial depende de habilitação prévia perante a SRF.

\section{REPETRO}

O Regime Aduaneiro Especial de Exportação e de Importação de Bens Destinados às Atividades de Pesquisa e de Lavra das Jazidas de Petróleo e de Gás Natural (Repetro), admite a possibilidade, conforme o caso, de utilização dos seguintes tratamentos aduaneiros: exportação com saída fictícia do território nacional e posterior aplicação do regime de admissão temporária, no caso de bem de fabricação nacional, vendido à pessoa sediada no exterior; exportação, com saída fictícia do território nacional, de partes e peças de reposição destinada aos bens já submetidos ao regime aduaneiro de admissão temporária; e importação, sob o benefício de drawback, na modalidade de suspensão de matérias-primas, produtos semielaborados ou acabados e de partes ou peças utilizadas na fabricação dos bens constantes de relação elaborada pela SRF, inclusive máquinas e equipamentos sobressalentes, ferramentas e aparelhos destinados a operacionalidade dos bens. 
O regime é aplicável aos bens relacionados pela $\mathrm{SRF}$, inclusive às máquinas e equipamentos sobressalentes, às ferramentas e aparelhos destinados a garantir a operacionalidade dos bens admitidos no regime.

\section{REPEX}

O Regime Aduaneiro Especial de Importação de Petróleo Bruto e Seus Derivados (REPEX) é o que permite a importação desses produtos, com suspensão do pagamento de impostos, para posterior exportação, no mesmo estado em que foram importados.

O regime somente é concedido a empresa previamente habilitada pela SRF, e que possua autorização da Agência Nacional de Petróleo para exercer as atividades de importação, exportação e refino dos referidos produtos.

A importação poderá ser feita com ou sem cobertura cambial e a exportação será efetuada exclusivamente em moeda de livre conversibilidade. O prazo de vigência do regime será de 90 dias, prorrogável por uma única vez por igual período.

Será admitida a utilização do produto importado para abastecimento interno, no prazo de vigência do regime, desde que cumprido o compromisso de exportação estabelecido.

\section{TRÂNSITO ADUANEIRO.}

O Regime Especial de Trânsito Aduaneiro é o que permite o transporte de mercadorias, sob controle aduaneiro, de um ponto a outro do território aduaneiro, com suspensão de tributos. A natureza jurídica deste regime é a suspensão das obrigações tributárias, geradas com a entrada e a saída de mercadoria em território nacional.

A sua natureza econômica decorre do fato de a mercadoria transitar de um ponto a outro do território aduaneiro, sem integrar a riqueza nacional ou para ela contribuir, em virtude da suspensão da exigibilidade tributária por tempo determinado.

O trânsito aduaneiro possibilita a interiorização das atividades aduaneiras que seriam realizadas nas repartições de fronteira, proporcionando a diminuição de trabalho dessas repartições e desafogando, assim, a zona primária.

O transporte de mercadorias em operação de trânsito aduaneiro pode ser efetuado por empresas transportadoras previamente habilitadas pela SRF.

\section{ZONAS DE PROCESSAMENTO DE EXPORTAÇÃO}

As Zonas de Processamento de Exportação (ZPEs) se caracterizam por serem áreas especiais onde se aplicam as regulamentações e os vínculos aduaneiros normais da economia. Esses espaços constituem um tipo particular de zona franca. 
Modelo de estratégia que há muitos anos vem sendo observado, as ZPEs tem um histórico que envolve ao longo do seu desenvolvimento a participação de vários atores do cenário internacional, tais como a China - mencionada anteriormente - e os Tigres Asiáticos9.

\section{HISTÓRICO DAS ZONAS DE PROCESSAMENTO DE EXPORTAÇÃO}

Assim como as mudanças ocorridas no cenário doméstico da economia chinesa apresentaram repercussões no cenário político-social do país, outras nações passaram por mudanças semelhantes - adotando políticas de bases sólidas para suas economias que levaram a abertura aos mercados internacionais - e distintas ao mesmo tempo que lidavam com tradições sócioeconômicas e culturais diferentes entre si.

A partir da década de 80, alguns países do Pacífico começaram a apresentar altos índices de crescimento mundial e interferência no mercado mundial, sendo por isso designados tigres asiáticos. A denominação de cunho agressivo é exatamente a característica fundamental dos quatro países que formam esse grupo (Hong Kong, Singapura, Coreia do Sul e Taiwan (Formosa). Eles utilizaram estratégia arrojada de atração de capital estrangeiro - apoiada na mão-de-obra barata e disciplinada, na isenção de impostos e nos baixos custos de instalação de empresas - constituia-se, dessa maneira a base da ZPE que se conhece atualmente.

\section{O COMEÇO: AS ZPES E OS TIGRES ASIÁTICOS}

A expansão dos Tigres Asiáticos teve um momento decisivo que correspondeu a crise da economia japonesa na década de 80. Essa expansão foi decisiva para criar um dinâmico mercado em toda a área circundante do Pacifico. Esse crescimento foi seguido pela Coréia do Sul, que na década de 60 era um dos países mais pobres do mundo e que se transformou numa semi-industrializada nação de renda média ao final da década de 90 - depois de iniciar suas reformas internas. Dessa mesma maneira, o progresso de Taiwan seguiu o mesmo rumo.

Passada a década de 80 e suas mudanças, o final dos anos 90 apresentou os bons resultados dos investimentos feitos na década anterior. Dessa maneira, as exportações chegavam a $202 \%$ do PNB (produto nacional bruto) em Singapura e a 132\% em Hong Kong. O índice de crescimento era alto nos tigres, e, a despeito da crise asiática, a população tinha um alto nível de alfabetização e a economia girava em torno da construção naval, produtos têxteis, petroquímicos e equipamentos elétricos. O crescimento mais notável ocorreu principalmente na economia de entrepostos. Hong Kong, graças à economia de mercado puro e, apesar de sobrecarregada pelas desvantagens do colonialismo (anteriormente existente enquanto colônia britânica), elevou sua renda per capita para cerca de seis vezes mais que a da China continental.

Os Tigres compartilham muitas características com outras economias asiáticas, como Japão e China. Iniciaram o que passou a ser visto como uma particular aproximação asiática do

\footnotetext{
9 A expressão Tigres Asiáticos refere-se às economias de Hong Kong, Singapura, Coreia do Sul e Taiwan (Formosa); esses territórios e países apresentaram grandes taxas de crescimento e rápida industrialização entre as décadas de 1960 e 1990. (Wikipédia).
}

Observatório - Monografias em Comércio Exterior, Ano 1, Vol. 1 
desenvolvimento econômico. Alguns desses países estavam na década de 1960 com indicadores sociais semelhantes a de países africanos altamente estagnados; as principais transformações basearam-se em acesso à educação e criação de infra-estrutura de transportes (fundamental para a exportação competitiva).

Com o tempo, o termo Tigre tornou-se sinônimo de nação que alcançou o crescimento com um modelo econômico voltado para exportação. Recentemente, nações do Sudeste asiático, como Indonésia, Malásia, Filipinas e Tailândia também passaram a ser consideradas Tigres.

\section{AS ZPES E A ECONOMIA DOS TIGRES}

Assim como a China adotou mecanismos estratégicos para o desenvolvimento de sua economia, os Tigres asiáticos alcançaram o progresso com um modelo econômico exportador que se baseava na fabricação de todo tipo de produto para exportá-los a países industrializados. As facilidades para destinar as mercadorias para o exterior se caracterizavam, entre outros, pela queda de barreitas alfandegadas, incentivo à implantação de industrias exportadores, mão-de-obra barata e qualificada e a aquisição de matérias-primas. Porém, em sentido contrário, essas nações se tornaram hostis a importações para o consumo doméstico que era desestimulado por altas tarifas governamentais.

Eles encaram a educação como um meio de aumentar a produtividade. Os países melhoraram o sistema educacional em todos os níveis, assegurando que toda criança freqüente o ensino fundamental e o ensino médio. Também investiu-se na melhoria do sistema universitário.

Como os Tigres eram relativamente pobres durante a década de 1960, tinham abundância de mão-de-obra barata. Juntamente com a reforma educacional eles conseguiram aproveitar essa vantagem, criando uma força de trabalho de baixo custo, mas muito produtivo.

Eles promoveram a igualdade na forma de reforma agrária, para promover o direito de propriedade e para assegurar que os trabalhadores rurais não se prejudicassem. Também foram implantadas políticas de subsídios à agricultura.

O êxito dos Tigres Asiáticos e da China pode ser percebido pela relação entre as ZPEs e os demais fatores que proporcionaram o desenvolvimento dessas nações, tais como um sério planejamento econômico; investimento de capital estrangeiro (pricipalmente japones e norteamericano que enxergavam os Tigres Asiáticos como países de localização estratégica para fortalecer o capitalismo contra o socialismo na época da Guerra Fria); exploração da força de trabalho, relativamente barata, que compensava a falta de matérias-primas - as férias muito reduzidas, a jornada de trabalho elevada e a previdência social restrita; distribuição mais equilibrada de renda em relação a outros países capitalistas; Estados altamente centralizados e ditatoriais e as próprias economias voltadas fundamentalmente para o mercado externo.

\section{CLASSIFICAÇÃO DAS ZONAS DE PROCESSAMENTO DE EXPORTAÇÃO}

A funcionalidade dessas áreas se caracteriza da seguinte maneira: as mercadorias que nelas transitam (ou nelas são produzidas) são consideradas como não tendo ingressado (ou não 
tendo sido produzidas) no território aduaneiro do país. As zonas francas que contam apenas com este benefício de natureza aduaneira, mais algumas facilidades de infra-estrutura e de serviços de apoio, são chamadas de zonas francas comerciais. As diferenças que existem entre essas e as zonas francas industriais reside no fato de que nas últimas há a inclusão de outros incentivos adicionais, tais como isenções tributárias, liberdade cambial, legislação trabalhista mais flexível etc., com o objetivo básico de atrair investimentos produtivos.

As Zonas Francas podem ainda ser classificadas em privadas ou públicas e abertas - quando situadas em áreas afastadas e atrasadas, onde as distâncias e a precariedade da infra-estrutura tornam dispensáveis, para efeito do controle aduaneiro, o isolamento da área, ou fechadas separadas por cerca, quando próximas a centros urbanos servidos com múltiplas vias de acesso.

Pelas suas próprias características, as zonas francas abertas estão mais fortemente associadas a políticas de desenvolvimento regional e, por isso, costumam oferecer incentivos mais amplos, de modo a compensar maiores desvantagens locais nas regiões onde estão inseridas. As ZPEs também não incluem os depósitos francos, existentes nos países da União Européia, que são edifícios isolados e sob controle aduaneiro, onde são permitidas operações comerciais bastante similares às realizadas nas zonas francas. Não são, porém, computadas como zonas francas as "duty-free shops" existentes em aeroportos internacionais nem os "paraísos fiscais", onde são realizadas operações com valores mobiliários, em condições de anonimato bancário e isenções fiscais.

Podemos, então, caracterizar as ZPEs brasileiras como zonas francas industriais fechadas. Em alguns Estados elas são públicas (totalmente pertencentes ao governo estadual); em outros, privadas (foram licitadas e passadas a grupos privados); e, na maioria dos casos, mistas resultados de parcerias público-privadas (PPP) entre os governos estaduais e municipais, associados a grupos privados. A família das zonas francas conta ainda, no Brasil, com a Zona Franca de Manaus (ZFM) e as sete Áreas de Livre Comércio (ALC), localizadas nas áreas de fronteira da Amazônia: Tabatinga (AM), Brasiléia-Epitaciolândia (AC), Cruzeiro do Sul (AC), Guajará-Mirim (RO), Pacaraima (RR), Bonfim (RR) e Macapá-Santana (AP). Todas elas são zonas francas abertas, sendo que as ALC são comerciais e a ZFM tem a particularidade de ter uma parte comercial (o centro comercial urbano) e uma parte industrial (o Distrito Industrial de Manaus).

\section{O PAPEL DAS ZONAS DE PROCESSAMENTO DE EXPORTAÇÃO NO BRASIL}

A implantação das ZPEs é algo distinto para cada país e região, porque, assim como cada área características particulares, os fatores que orientam o sucesso dessas iniciativas não podem ser tratados com o mesmo juízo de valor. Segundo Kelleher e Kavanagh (1996) isso pode ser claramente percebido, pois, muito embora "a atividade da zona franca da maioria dos países seja concentrada em artigos de vestuário e na montagem de componentes eletrônicos para comercialização nos países desenvolvidos", realidade brasileira se caracteriza pela utilização de mão-de-obra cara (comparando a regiões como América Central, Caribe e África), por exemplo. 
O papel fundamental das ZPEs é tornar o mercado produtor brasileiro cada vez mais competitivo e combater e eliminar a burocracia, assim como suprimir barreiras e facilitar o comércio.

\section{VIABILIDADE DAS ZONAS DE PROCESSAMENTO DE EXPORTAÇÃO NO BRASIL.}

A necessidade de implantação de ZPEs no Brasil é motivo de discordância entre autoridades, pois, apesar de pertencerem à mesma família, existem diferenças essenciais entre as zonas francas e o modelo de ZPE brasileiro, principalmente, porque o assunto ainda não é amplamente discutido. Além disso, a forma de incentivo que será oferecida àqueles que se enquadrarem na sistemática dessas fazendo com que indagações e receios se façam presentes. Diante do exposto, a deputada federal Dr ${ }^{\mathrm{a}}$. Clair (PT-PR), afirmou: "Se dermos todos esses benefícios a essas grandes empresas, que desequilíbrio não podemos gerar em relação às empresas brasileiras?", questionou referindo-se aos incentivos fiscais previstos no projeto. Além desses questionamentos, também a manifesta preocupação quanto à situação das empresas nacionais diante da criação das ZPEs. Segundo a deputada do PT-PR, "Essas empresas estrangeiras vão ter benefícios fiscais e podem sair do Brasil a qualquer momento", ponderou.

A criação das ZPEs dá lugar a outras discussões positivas, tais como a redução da carga tributária das pequenas empresas do País, reformas de caráter político-econômicas que promovam a infra-estrutura funcional dos agentes econômicos (Estado, empresas, consumidores, etc.) e causem efeitos positivos dentro e fora dessas zonas. Nesse sentido, quando empresas instaladas nas ZPEs vendem para o exterior, não há concorrência. Segundo Helson Braga, não há competição desigual, pois "Elas (empresas) só concorrem quando vendem para o mercado interno. Nesse caso, todos os impostos sobre o produto incidem normalmente". Quanto ao reflexo das isenções fiscais na arrecadação do governo e a possibilidade de resistência da Receita Federal em relação às ZPEs. Para o deputado Walter Barelli (PSDB-SP), por sua vez, "Não se pode falar em perda de arrecadação quando a arrecadação não existe. De qualquer forma, a Receita Federal como instituição não tem posição contrária às ZPEs", explicou Helson Braga. Além de atrair investimentos externos, a instalação das ZPEs visa a geração de empregos, o fortalecimento da balança de pagamentos e a promoção do desenvolvimento regional

O Brasil não é o único a se preocupar com criação de projetos para o desenvolvimento econômico que visem uma maior participação no comércio internacional. Segundo o International Labour Office, "há cerca de três mil zonas de processamento de exportação (ZPE) ou mecanismos similares em 116 países, gerando aproximadamente 37 milhões de empregos diretos, sendo 30 milhões só na China".

Para o professor da Universidade Federal do Rio de Janeiro (UFRJ) Helson Cavalcante Braga observou que é no sudeste asiático que os casos de sucesso das ZPEs são mais aparentes. "A China cresce fundamentalmente alavancada por suas zonas especiais", informou em audiência pública sobre as ZPEs realizada pela Comissão de Trabalho, Administração e Serviço Público. 


\section{METODOLOGIA}

A pesquisa analisa a estrutura com a qual as estratégias e as políticas de desenvolvimento do comércio internacional são colocadas em curso, e, os efeitos gerados, no âmbito macroeconômico. A metodologia escolhida foi à exploratória-descritiva, utilizando-se dados secundários.

\section{TIPO DE PESQUISA}

A presente pesquisa caracteriza-se como um estudo descritivo exploratório que, segundo ALEXANDRE (2003) "visa desenvolver, esclarecer e modificar conceitos e idéias; envolve levantamento bibliográfico e documental, entrevistas e estudos de caso". Neste estudo, são descritos os documentos extraídos das bibliografias consultadas. Essas informações são de grande relevância para o crescimento acadêmico, social e econômico.

\section{UNIVERSO E AMOSTRA}

O universo deste trabalho compreende os modelos de projeto de ZPEs desenvolvidos no mundo até o presente momento. Conforme VERGARA (2000), população amostra ou simplesmente amostra "é uma parte do universo (população) escolhido segundo algum critério de representatividade". A amostra pesquisada aqui se refere aos modelos de ZPE votado em lei pelo Congresso Nacional e adaptado à realidade norte-riograndense pelo Estado.

\section{PROCEDIMENTOS DE COLETA DE DADOS}

Os dados serão coletados em documentos, levantamentos bibliográficos, bem como pesquisas na Internet, assim como na literatura especializada existente sobre o assunto e entrevistas feitas a autoridades e instituições. Por fim, ocorrerá a reunião dos dados e a correspondente análise.

\section{RESULTADO}

A Zona de Processamento de Exportação constitui um espaço onde se estabelecem indústrias voltadas para o mercado externo. Nesse ambiente a exportação é a palavra de ordem. Na área da ZPE, poderão se instalar indústrias tanto dos setores existentes no Estado, tais como alimentício, químico-petroquímico, como também de segmentos diversos, como eletroeletrônico, metal-mecânico, matérias plásticas e brinquedos, minerais, inclusive uma refinaria de petróleo.

As ZPEs são criadas através de Decreto que delimita a área, à vista de propostas de Estados ou de Municípios, em conjunto ou isoladamente. A instalação dessas áreas é de inteira responsabilidade dos Estados e não cabe ao Tesouro Nacional assumir qualquer ônus para a implantação. Para efeito de controle aduaneiro a ZPE é considerada zona primária. 
A ZPE tem por finalidade o fortalecimento do balanço de pagamentos, redução dos desequilíbrios regionais e a promoção da difusão tecnológica e do desenvolvimento econômico e social. O regime tributário, cambial e administrativo das Zonas de Processamento de Exportação foi inicialmente definido na lei 2.452 de 29 de junho de 1988 no governo Sarney e modificado com grandes mudanças pelo Projeto de Lei recém votado no Senado de $n^{\circ}$ 146, de 1996 ( ${ }^{\circ}$ 5.456/2001, na Câmara dos Deputados) e vetado pelo Presidente da Republica, Luís Inácio Lula da Silva, na parte cambial e tributária alegando descompasso com as modificações recentes nas legislações tributárias do país. Porém, um acordo com o Parlamento toda a parte vetada será encaminhada ao Congresso com as adequações necessárias por meio de Medida Provisória (MP). As referidas leis foram colocadas no anexo deste trabalho para uma melhor compreensão do leitor.

\section{LEGISLAÇÃO BRASILEIRA}

A regulamentação da criação das ZPEs está regida pela legislação brasileira assegura a simplificação de procedimentos burocráticos, na importação e na exportação; isenção de Imposto de Importação (II) para máquinas e equipamentos (novos ou usados) e insumos importados; isenção de Impostos sobre Produtos Industrializados (IPI) e de outras taxas e contribuições federais - Adicional ao Frete para Marinha Mercante (AFRMM); isenção de Imposto de Renda (IR) sobre remessa de lucros, dividendos e quaisquer outros pagamentos feitos a não residentes; o direito à constituição de empresa $100 \%$ estrangeira e/ou nacional, com capital externo constituído do produto de conversão da moeda estrangeira, e também, com a internação de bens de origem externa e a livre disponibilidade das divisas obtidas na exportação por um prazo de 20 anos, podendo ser prorrogável por sucessivos períodos de tempo. É importante ressaltar que, na legislação atual, é permitida às empresas que exportarem toda a sua produção a internação dos resíduos do processo industrial.

\section{TRATAMENTO CONCEDIDO ÀS EMPRESAS NAS ZPES}

$\boldsymbol{A}$ legislação existente determina também o tratamento oferecido às empresas instaladas nas referida áreas que será de caráter administrativo, tributário, cambial, financeiro e trabalhista. Partindo do ponto administrativo, será respeitado o cumprimento da estabilidade das regras vigentes na data da aprovação do projeto por prazos de até 20 anos renováveis, por idênticos períodos; as importações estão dispensadas da obtenção de guias e autorizações de órgãos federais exceto aquelas necessárias ao controle de ordem sanitária, segurança nacional e proteção ambiental; a inexistência de quaisquer restrições na importação de máquinas e equipamentos usados; as exportações são totalmente isentas de guias ou outras licenças e autorizações federais, exceto no caso de produtos que estejam sujeitos ao regime de cotas no exterior, cuja destinação deve ser controlada; a inexistência de quaisquer taxas nas operações de comércio exterior, e total liberdade para realizar e receber remessas financeiras do exterior, independentemente de autorização ou controle do Banco Central.

No aspecto tributário, a legislação determina que aja a isenção do II, IPI, FINSOCIAL, AFRMM e Imposto sobre Operações Financeiras (IOF) nas importações, realizadas tanto na fase de implantação como na de operação; as exportações estão sujeitas ao mesmo tratamento tributário das demais exportações do País, e a tributação dos lucros auferidos estará sujeita às normas e alíquotas vigentes, na data da aprovação do projeto, salvo mais favorável que venha a ser instituído posteriormente. 
O tratamento cambial cedido às empresas instaladas nas ZPEs permite a livre disponibilidade de todas as divisas obtidas com suas operações - as realizadas com o exterior não dependem de contrato de câmbio; e a manutenção de conta em moeda estrangeira em banco autorizado a operar em câmbio.

Financeiramente a intervenção legal permite que as empresas em ZPE não possam obter financiamento, de qualquer espécie, no mercado financeiro doméstico. Não existe, porém, qualquer restrição a que seus acionistas, pessoas físicas ou jurídicas, domiciliadas fora de ZPE, o façam.

No aspecto trabalhista a regulamentação exige que as normas existentes na legislação trabalhista ordinária do País sejam aplicadas às empresas em ZPE e que, a título de observação, essas companhias não podem desfrutar, a nível federal, de quaisquer incentivos previstos na legislação de regência.

As empresas instaladas nas ZPEs têm o compromisso de realizar gastos mínimos nos níveis estipulados pelo Conselho Nacional de Zonas de Processamento de Exportação - CZPE, quando da aprovação de investimentos, nas fases de instalação e operação, podendo ser computados com aquisição de máquinas, equipamentos, insumos, serviços (inclusive construção civil), mão-de-obra e encargos sociais, além de contratar empresa independente de auditoria para acompanhar suas operações sempre que solicitado pelo CZPE.

Em linhas gerais, as principais características que se pode observar nas transações comerciais em Zona de Processamento de Exportação são: a venda de produtos manufaturados para o mercado doméstico em quantidades de $20 \%$, contra em apenas $10 \%$ que eram permitidos anteriormente. Essa permissão foi amplamente discutida e as vendas de mercadorias oriundas de empresas instaladas nas ZPEs para o mercado interno terá tratamentos tributário, fiscal e cambial que é dado às importações do País. Quanto a essas operações, as "importações" ou "compras no Brasil" são operacionalizadas com semelhança ao tratamento das exportações do País, embora as compras feitas no exterior, ou seja, as importações propriamente ditas recebem isenção tributária, tratamento fiscal e cambial privilegiados. Em todos esses casos, a mercadoria reintroduzida no país, procedente da ZPE será processada pelo Sistema Integrado de Comércio Exterior - SISCOMEX.

\section{INCENTIVOS}

Investir em Estados com potencial de crescimento a ser explorado é um grande negócio. Alguns governos estaduais, tais como Santa Catarina, Sergipe e mais recentemente, Rio Grande do Norte e Ceará, vêm dando importância a esse tema e estão rediscutindo formas de incentivar e estimular o desenvolvimento sócio-econômico regional. Do incentivo fiscal ao financeiro, passando por melhorias em infra-estrutura, as oportunidades ofereçam aos novos horizontes à abertura das portas que governos e iniciativa privada precisam para promover o tal acréscimo.

Embora a lei que torna as ZPEs uma realidade tangível e praticamente nenhum Estado possua algum projeto de área econômica especial elaborada, percebe-se que os incentivos fiscais estão sempre em pauta e, talvez, devido a isso não desperta o interesse de implantar uma ZPE 
- algo que requer infra-estrutura disponível, como o Rio Grande do Norte, por exemplo, que não possui tal projeto de viabilidade econômica.

Além das vantagens fiscais oferecidas, as empresas que vão operar nas ZPEs deverão encontrar a infra-estrutura necessária ao desempenho das suas atividades, tais como: área totalmente segura; sistema de manutenção e conservação do complexo; facilidades de embarques da produção junto ao sistema aeroportuário e portuário; apoio logístico, permanente, da empresa administradora da ZPE e o arrendamento de espaços e/ou galpões industriais. Esse mecanismo é suficientemente flexível para ajustar-se a diferentes estratégias empresariais.

Poderão usufruir dos incentivos e estímulos os empreendimentos industriais necessários e prioritários para o desenvolvimento regional. Entendem-se como empreendimentos prioritários industriais aqueles que proporcionem ou contribuam direta ou indiretamente para a elevação do nível de emprego e renda; a descentralização econômica e espacial das atividades produtivas; a modernização tecnológica do parque industrial; e a preservação do meio ambiente.

Em se tratando de ZPE, o tratamento especial que é oferecido às empresas exportadoras em virtude da Lei Kandir que suspende a arrecadação dos impostos da União (IOF, IPI, PIS/PSEP, COFINS) e dos Estados (ICMS) não é diferente ao oferecido às companhias da ZPE. Nesse sentido, uma vez que as empresas instalada naquele espaço estarão sob um tratamento diferenciado, o Estado terá a possibilidade de outras fontes de arrecadação, principalmente, as relacionadas a rede de serviços oriundos dessas áreas.

O Governo do Estado do Rio Grande do Norte, apesar de estar mobilizando recursos para projetos que indiretamente contribuirão para o funcionamento do complexo do "aerotrópolis", como as obras da região metropolitana - conclusão da Ponte Nilton Navarro e melhoria do acesso entre o futuro aeroporto e a Capital não têm demonstrado interesse pelo planejamento da Área Econômica Especial do Estado, uma vez que o desenvolvimento da atividade industrial não é colocado com a sua devida importância para a geração de emprego e renda da população norte-riograndense. Percebe-se ainda que o desconhecimento do tema permite o surgimento de opiniões vagas, principalmente, no que diz respeito aos benefícios fiscais e às formas de arrecadação.

A Federação das Indústrias do Rio Grande do Norte (FIERN) tem permanecido estática ao tema, uma vez que não tem se posicionado de maneira sólida nem a favor nem contra. Em outros Estados brasileiros o assunto já deu início a ações conjuntas entre as suas federações e seus governos ora favoráveis - como o Ceará, ora contra - São Paulo (o Governo paulista e a classe empresarial têm se revelado fortes opositores do projeto de ZPE, sobretudo, no que diz respeito à instalação delas em regiões mais carentes - Nordeste).

Procurados no momento do levantamento dos dados, o Governo estadual e a FIERN demonstraram pouca familiaridade com o assunto. Segundo os jornais, como o Diário de Natal, existe um conselho formado entre as referidas instituições que fora criado para tratar especificamente do projeto de viabilidade econômica da ZPE do RN. Porém, o que não se conhece é quem compõe essa ilustre equipe, que tem em mãos um grandioso projeto a ser idealizado, e quais os resultados levantados até o momento. 
Um projeto de Área Econômica Especial, mais que uma iniciativa complexa de ações conjuntas, é uma alternativa de crescimento voltado para o desenvolvimento descentralizado dos setores produtivos. Com a instalação de uma ZPE, o RN terá mais autonomia econômica em relação aos Estados vizinhos, sobretudo, no aspecto da logística e do transporte - o aeroporto será um trampolim para os mercados norte-americano, europeu, africano e asiático conforme mostra a figura 3, e proporcionará mais um mecanismo de desenvolvimento da integração regional - ao mesmo tempo em que vai interagir com outros Estados, proporcionará um crescimento econômico-social na região.

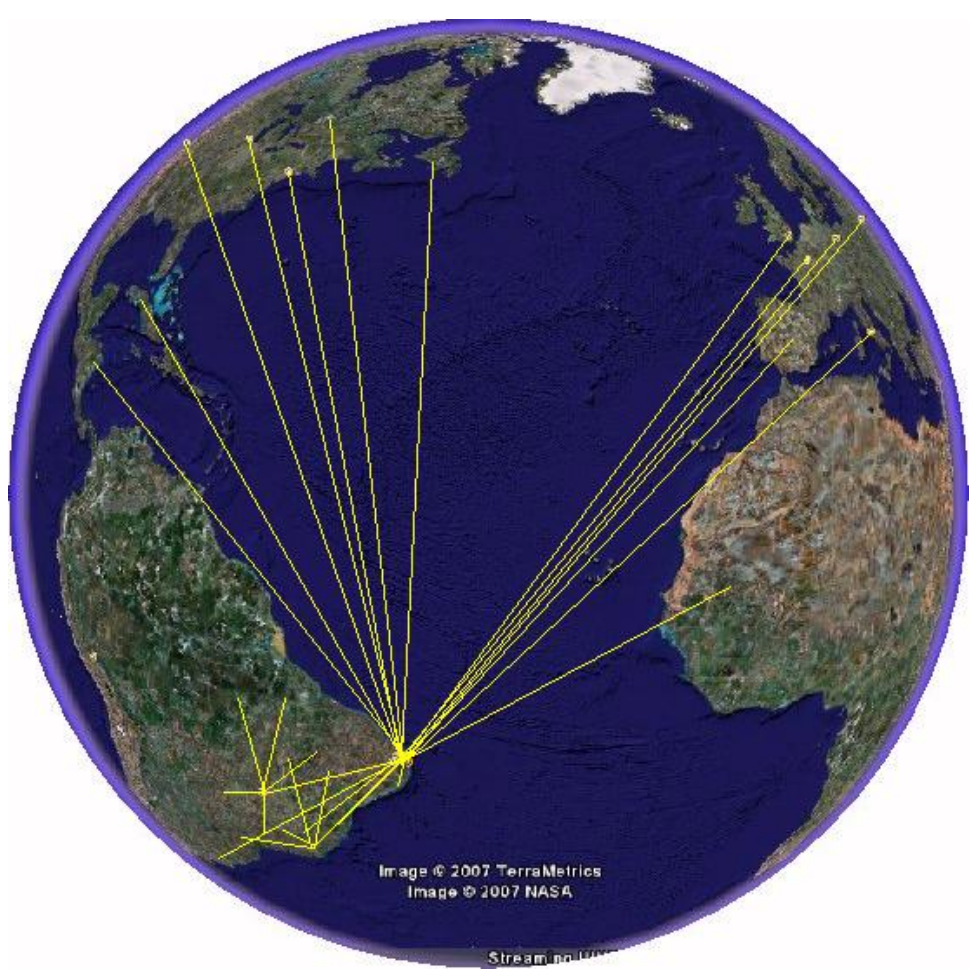

FIGURA 3 - Localização do Aeroporto de São Gonçalo do Amarante-RN em Relação ao

\section{Brasil e o mundo}

\section{CONSIDERAÇÕES E RECOMENDAÇÕES}

A presente pesquisa empreendida no cenário das áreas Econômicas Especiais aponta resultados satisfatórios para o campo científico, assim como desempenhos contrários a realidade dos aspectos sócio-econômicos, sobretudo, do Estado do Rio Grande do Norte. Diante destas informações, acredita-se que o pioneirismo deste projeto reforce cada vez mais o prazer pelo conhecimento em assuntos pouco explorados e promova, ao mesmo instante, a contrapartida da sociedade para o despertar de uma atuação pró - ativa com as causas pertinentes ao desenvolvimento sustentável, geração de emprego e renda, assim como a melhoria na qualidade de vida da população.

O diagnóstico geral acerca desse tema, percebido ao longo de reflexões, é de um cenário favorável à implantação de novas estratégias que promovam a inserção cada vez maior da economia no mercado exportador. Diante disso, observa-se que no aspecto técnico, o Estado do Rio Grande do Norte tem apresentado um crescimento na balança comercial brasileira 
considerável e que, embora ainda não utilize plenamente seu potencial mercadológico, possui condições favoráveis à resolução de suas dificuldades uma vez que tem sido cada vez maior a entrada de investimentos estrangeiros.

Vantagens competitivas, tais como localização geográfica favorável - proximidade com Europa, África e Ásia, fazem do Estado um trampolim, não apenas para a economia doméstica, como também para a América Latina alcançar novos mercados aumentando suas receitas e reduzindo custos. Diante disso, tecnicamente o Rio Grande do Norte estará um passo adiante uma vez que tem sua infra-estrutura melhorada ao ponto de se adequar de maneira mais consistente à dinamicidade do Comércio Internacional. Com a conclusão de alguns projetos em andamento, tais como o Aeroporto Internacional de São Gonçalo do Amarante, o Estado aumentará o fluxo de turismo de passageiros nacionais e internacionais levando ao crescimento da oferta de emprego e geração de renda da população.

A oferta de infra-estrutura é fator crescimento econômico e de atração de investimentos para a região. Nesse sentido, o desenvolvimento norte-riograndense apresenta uma limitação, consideravelmente grave: existe uma ineficiência de políticas públicas que promovam um desenvolvimento equilibrado. Embora seja imprescindível o interesse público de proporcionar condições favoráveis ao funcionamento de sua economia, é também necessário o planejamento de ações que permitam uma maior independência tecnológica, política e industrial. Observa-se como indispensável à criação de um projeto de Área Econômica Especial juntamente ao Aeroporto Internacional de São Gonçalo do Amarante, uma vez que, em virtude da finalidade do mega-projeto, é prevista uma grande movimentação de cargas (1,5 milhão de toneladas anuais, com capacidade de movimentação de aeronaves de grande porte) e passageiros (40 milhões de turistas por ano). Isso tudo é possível, segundo o exDeputado Federal Ney Lopes (DEM-RN):

\footnotetext{
"numa época de globalização, em que $80 \%$ das commodities passam a ser transportadas por via aérea, e não mais em navios, a não ser produtos como o ferro, de peso considerável, a construção de aeroportos com infra-estrutura para pouso de aviões de grande porte capacidade para 800 passageiros (Airbus A380) e cargas 10 vezes superiores às transportadas atualmente, deve está intimamente ligada à implantação e funcionamento de uma Área Econômica Especial.”
}

O modelo de "aerotrópolis" é visto como a força motriz de uma dinâmica e complexa junção de fatores produtivos - infra-estrutura, tecnologia, funcionalidade (implantação de indústrias que irão consumir matérias-primas e gerar produtos - que poderão ser exportados) e mão-deobra, que se completam entre si.

Diante do caráter físico e estrutural dos elementos que fazem parte dos cenários macroeconômicos e político-sociais, nos quais o Estado está inserido, verifica-se que há uma indiferença por parte das Instituições ${ }^{10}$ que não despertaram sua sensibilidade frente à promoção de um crescimento mais consolidado e amplo. Em curto prazo ainda não causou impactos potencialmente nocivos a sua manutenção no mercado, porém, se não for tomado um posicionamento diferente, o Estado corre o risco de perder uma oportunidade ímpar de se projetar industrialmente no mercado e permanecer preso à dependência de consumidores de matérias primas e commodities.

${ }^{10}$ A expressão Instituições compreende não apenas Governo Estadual, mas também federações e empresários. 


\section{CONSIDERAÇÕES FINAIS}

Concluo este Projeto com a certeza de que a ZPE é uma grande oportunidade do Estado do Rio Grande do Norte conseguir se lançar a níveis excelentes o seu desenvolvimento econômico-social e tecnológico.

Diante da atual conjuntura mundial, na qual os mercados interagem entre si tornando único o ambiente internacional, o RN se prepara de forma favorável a essa realidade com a adequação de sua infra-estrutura, como, por exemplo, a construção do grande aeroporto de São Gonçalo do Amarante.

O "aerotrópolis" constitui o passo inicial no caminho do desenvolvimento da região, uma vez que se caracteriza como a base de grandioso e espetacular projeto de funcionalidade dos recursos ali implantados - instalação de empresas, criação de usinas de geração de energia, etc.

Nesse sentido, é imprescindível a idealização, em caráter de urgência, de um projeto de Zona de Processamento de Exportação para o Rio Grande do Norte com a finalidade de adequar o Estado à realidade de sua futura infra-estrutura logística e produtiva, e às próprias vantagens competitivas diante de outros Estados brasileiros - localização geográfica com grandes mercados consumidores - que o colocam à frente no processo de crescimento econômicosocial e tecnológico do país.

Fonte de geração de inúmeros empregos, a ZPE atrairá empresas voltadas para o mercado internacional que irá demandar infra-estrutura, mão-de-obra e matérias primas. Nesse sentido, as Zonas Econômicas Especiais, como são denominadas as essas áreas, cumprem suas funções promovendo o desenvolvimento econômico, gerando emprego e renda e atraindo investimentos estrangeiros para o Estado.

\section{REFERÊNCIAS}

1. AlEXANDRE, M. J. O. Construçao do Trabalho Cientifico. São Paulo: Forense Universitari, 2003.

2. BERGAMINI, C. W. Psicologia aplicada à Administração de Empresas. São Paulo: Atlas, 1996.

3. BRASIL. Ministério do Desenvolvimento, Indústria e Comércio Exterior. Treinamento em Comércio Exterior. Brasília: SENAI, 2003.

4. CALDAS, R; AMARAL, C. Introdução à Globalização Noções Básicas de Economia, Marketing \& Globalização. São Paulo: Instituto Brasileiro de Direito Constitucional, 1998.

5. Kelleher, T; KAVAnagh, A. Zonas de Processamento de Exportação: o Programa Brasileiro e a Experiência Internacional. Brasília: SEBRAE, 1996.

6. LACERDA, A. Economia Brasileira. São Paulo: Saraiva, 2000.

7. MAURO, F. La Expansión Europea (1600-1870). Barcelona: Labor, 1968.

8. RUIZ, C. M. B. Os paradoxos do Imaginário. São Leopoldo: UNISINOS, 2003. 
9. SOUZA, N. L. Opinião VI. Brasília: Centro de Documentação e Informação, 2007.

10. VERGARA, S. C. Gestão de Pessoas. 2. ed. São Paulo: Atlas, 2000.

11. WALlERSTEIN, I.EI Sistema Mundial, SIGLO XXI. México: Editores, 1984, vol. 1.

12. WALLERSTEIN, I.EI Sistema Mundial, SIGLO XXI. México: Editores, 1984, vol. 2.

13. Ministério do Planejamento, disponível em:

<http://clipping.planejamento.gov.br/Noticias.asp?NOTCod=194043 > Acesso em: 27 out. 2006.

14. Câmara Federal. Disponível em:

<http://www.camara.gov.br/internet/agencia/materias.asp?pk=77201> Acesso em: 05 nov. 2006.

15. CCIL. Disponível em: <http://www.ccil-c.com> Acesso em: 5 mar. 2007.

16. COMEX NET. Disponível em:

<http://www.comexnet.com.br/comexnet/index.cfm?pag=regimes_aduaneiros.cfm> Acesso em: 27 out. 2006.

17. DESENVOLVIMENTO. Disponível em:

<http://www.desenvolvimento.gov.br/sitio/legislacao/resolucoes/czpe.php> Acesso em: 27 out. 2006.

18. WORD. Disponível em: <http://www.dw-world.de> Acesso em: 5 de mar. 2007.

19. FMPRE. Disponível em: <http://www.fmprc.gov.cn> Acesso em: 18 fev. 2007.

20. IMF. Disponível em: <http://www.imf.org> Acesso em: 6 mar. 2007.

21. IMIGRAÇÃO. Disponível em:

<http://www.mte.gov.br/Menu/imigracao/conselhonacional/Legislacao/rn/ResolNorm18.a sp> Acesso em: 27 out. 2006.

22. FOMENTO. Disponível em:

<http://www.mtfomento.mt.gov.br/noticias/noticia.asp?cod=70> Acesso em: 27 out. 2006.

23. ESTUDOS ESTATÍSTICOS. Disponível em:

<http://www.receita.fazenda.gov.br/aduana/EstudosEstatisticos.htm> Acesso em: 20 nov. 2006.

24. ANUÁRIO. Disponível em: <http://www.sebrae.com.br/anuario_mpe/links.asp> Acesso em: 20 nov. 2006.

25. TIGRES. Disponível em: 〈http://pt.wikipedia.org/wiki/Tigres_asi\%C3\%A1ticos> Acesso em: 2 fev. 
